\title{
Bacteriophages reduce Yersinia enterocolitica contamination of food and kitchenware
}

\author{
Jin Woo Jun ${ }^{\mathrm{a}, \mathrm{b}, 1}$, Se Chang Park ${ }^{\mathrm{a}, 1}$, Anu Wicklund ${ }^{\mathrm{b}}$, Mikael Skurnik ${ }^{\mathrm{b}, \mathrm{c}, *}$

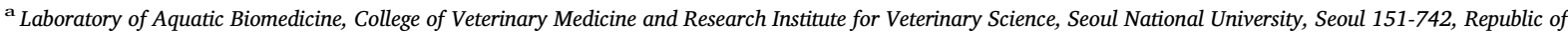 \\ Korea \\ ${ }^{\mathbf{b}}$ Department of Bacteriology and Immunology, Medicum, Research Programs Unit, Immunobiology, University of Helsinki, PO Box 21, 00014 Helsinki, Finland \\ ${ }^{\mathrm{c}}$ Division of Clinical Microbiology, Helsinki University Hospital, HUSLAB, Helsinki, Finland
}

\section{A R T I C L E I N F O}

\section{Keywords:}

Yersinia enterocolitica

Pork

Bacteriophage

Food

Kitchen utensil

\begin{abstract}
A B S T R A C T
Yersinia enterocolitica, the primary cause of yersiniosis, is one of the most important foodborne pathogens globally and is associated with the consumption of raw contaminated pork. In the current study, four virulent bacteriophages (phages), one of Podoviridae (fHe-Yen3-01) and three of Myoviridae (fHe-Yen9-01, fHe-Yen9-02, and fHe-Yen9-03), capable of infecting Y. enterocolitica were isolated and characterized. fHe-Yen9-01 had the broadest host range (61.3\% of strains, 65/106). It demonstrated a latent period of 35 min and a burst size of 33 plaque-forming units/cell, and was found to have a genome of $167,773 \mathrm{bp}$ with $34.79 \%$ GC content. To evaluate the effectiveness of phage fHe-Yen9-01 against $Y$. enterocolitica 0:9 strain Ruokola/71, we designed an experimental model of the food market environment. Phage treatment after bacterial inoculation of food samples, including raw pork $\left(4^{\circ} \mathrm{C}, 72 \mathrm{~h}\right)$, ready-to-eat pork $\left(26^{\circ} \mathrm{C}, 12 \mathrm{~h}\right)$, and milk $\left(4^{\circ} \mathrm{C}, 72 \mathrm{~h}\right)$, prevented bacterial growth throughout the experiments, with counts decreasing by 1-3 logs from the original levels of $2-4 \times 10^{3} \mathrm{CFU} / \mathrm{g}$ or $\mathrm{ml}$. Similarly, when artificially contaminated kitchen utensils, such as wooden and plastic cutting boards and knives, and artificial hands, were treated with phages for $2 \mathrm{~h}$, bacterial growth was effectively inhibited, with counts decreasing by $1-2 \operatorname{logs}$ from the original levels of ca $10^{4} \mathrm{CFU} / \mathrm{cm}^{2}$ or $\mathrm{ml}$. To the best of our knowledge, this is the first report of the successful application of phages for the control of $Y$. enterocolitica growth in food and on kitchen utensils.
\end{abstract}

\section{Introduction}

Yersiniosis is recognized globally as an important zoonotic disease, the initial symptoms of which include fever and abdominal pain that may be confused with appendicitis (CDC, 2016), and diarrhea, which is often bloody (CDC, 2016). Consumption of raw or undercooked contaminated pork is the main source of this disease in humans (Bottone, 1999). However, it can also be contracted through contact with someone who has handled a contaminated pork product (CDC, 2016) or contact with infected animals or their feces (CDC, 2016), and, less commonly, by ingestion of contaminated milk or untreated water.

The facultative anaerobic gram-negative coccobacilli Yersinia enterocolitica is the major cause of yersiniosis (Bottone, 1999). This bacterium is considered an important zoonotic pathogen in developed countries, being the third most commonly reported in the European Union (EFSA and ECDC, 2015) and the cause of almost 117,000 illnesses and 35 deaths in the United States every year (CDC, 2016).
Pathogenic $Y$. enterocolitica strains are commonly categorized into four serogroups: O:3, O:5,27, O:8, and O:9 (McNally et al., 2016).

Bacteriophages (phages), viruses that specifically infect bacteria, are abundant organisms, with a total population of approximately $10^{31}$ particles (Bergh et al., 1989). Lytic phages have been used as therapeutic and prophylactic agents to control bacterial infections, as they can lyse their target bacterial cells without disruption of the normal host microbiota (Maura and Debarbieux, 2011). In addition, phages have been recognized as potential tools to control bacterial pathogens in food instead of antibiotics, the application of which in food is becoming increasingly restricted due to their limitations. Indeed, phages have been successfully employed to control the growth of various foodborne pathogens, and are capable of lysing bacterial cells with high host specificity, preserving any beneficial bacteria present (Jun et al., 2014a). Food products can be contaminated by pathogens originating from the raw materials used to prepare them, or from humans that manufacture or process the product (Maura and Debarbieux, 2011).

\footnotetext{
* Corresponding author.

E-mail address: mikael.skurnik@helsinki.fi (M. Skurnik).

${ }^{1}$ These authors contributed equally to this work.
} 
Table 1

Bacterial strains used in this study and infectivity of the Yersinia phages fHe-Yen3-01, fHe-Yen9-01, fHe-Yen9-02, and fHe-Yen9-03.

\begin{tabular}{|c|c|c|c|c|c|c|c|}
\hline \multirow[t]{2}{*}{ Bacterial species $(n)$} & \multirow[t]{2}{*}{ Strain } & \multirow[t]{2}{*}{ Serotype $^{\mathrm{a}}$} & \multicolumn{4}{|l|}{ Host range $^{\mathrm{b}}\left(\mathrm{EOPs}^{\mathrm{c}}\right)$} & \multirow[t]{2}{*}{ Reference } \\
\hline & & & fHe-Yen3-01 & fHe-Yen9-01 & fHe-Yen9-02 & fHe-Yen9-03 & \\
\hline \multirow[t]{44}{*}{ Y. enterocolitica (81) } & $6471 / 76$ & $0: 3$ & $++(1.00)$ & $++(0.47 \pm 0.18)$ & $++(0.94 \pm 0.13)$ & $++(0.48 \pm 0.13)$ & Skurnik, 1984 \\
\hline & Ruokola/71 & $0: 9$ & - & $++(1.00)$ & $++(1.00)$ & $++(1.00)$ & Skurnik, 1984 \\
\hline & $10 / 84$ & NT & - & $+(0.64 \pm 0.06)$ & $+(0.77 \pm 0.09)$ & - & $\begin{array}{l}\text { Leon-Velarde } \\
\text { et al., } 2016\end{array}$ \\
\hline & 1539 & NT & - & - & - & - & $\begin{array}{l}\text { Leon-Velarde } \\
\text { et al., } 2016\end{array}$ \\
\hline & $8533 / 84$ & NT & $+(0.34 \pm 0.10)$ & $++(0.88 \pm 0.06)$ & $++(0.55 \pm 0.08)$ & - & $\begin{array}{l}\text { Leon-Velarde } \\
\text { et al., } 2016\end{array}$ \\
\hline & $659 / 83$ & K1, NT & - & $+(0.78 \pm 0.12)$ & $+(0.89 \pm 0.08)$ & - & $\begin{array}{l}\text { Leon-Velarde } \\
\text { et al., } 2016\end{array}$ \\
\hline & $4367 / 83$ & K1, NT & - & - & - & - & $\begin{array}{l}\text { Leon-Velarde } \\
\text { et al., } 2016\end{array}$ \\
\hline & $20373 / 79$ & $0: 3$ & $++(0.62 \pm 0.08)$ & $++(0.77 \pm 0.07)$ & $++(0.54 \pm 0.06)$ & - & $\begin{array}{l}\text { Leon-Velarde } \\
\text { et al., } 2016\end{array}$ \\
\hline & 5854 & $0: 3$ & $++(0.65 \pm 0.03)$ & $++(0.74 \pm 0.06)$ & $++(0.34 \pm 0.05)$ & - & $\begin{array}{l}\text { Leon-Velarde } \\
\text { et al., } 2016\end{array}$ \\
\hline & $9568 / 79$ & $0: 3$ & $++(0.56 \pm 0.04)$ & $++(0.70 \pm 0.07)$ & $++(0.51 \pm 0.10)$ & - & $\begin{array}{l}\text { Leon-Velarde } \\
\text { et al., } 2016\end{array}$ \\
\hline & JD E766 & $\mathrm{O}: 1,2,3$ & $+(0.11 \pm 0.08)$ & - & - & - & $\begin{array}{l}\text { Schiemann and } \\
\text { Devenish, } 1982\end{array}$ \\
\hline & gc $3973-76$ & $\mathrm{O}: 4$ & - & - & - & - & Kay et al., 1983 \\
\hline & RB E701 & $\mathrm{O}: 4,32$ & $++(0.72 \pm 0.09)$ & - & - & - & $\begin{array}{l}\text { Perry and } \\
\text { Brubaker, } 1983\end{array}$ \\
\hline & $14693 / 84$ & O:5 & - & - & - & - & $\begin{array}{l}\text { Leon-Velarde } \\
\text { et al., } 2016\end{array}$ \\
\hline & $298 / 85 a 2$ & $0: 5$ & $+(0.14 \pm 0.04)$ & $+(0.71 \pm 0.10)$ & $+(0.15 \pm 0.06)$ & - & $\begin{array}{l}\text { Leon-Velarde } \\
\text { et al., } 2016\end{array}$ \\
\hline & $20109 / 83$ & O:5 & - & $+(0.91 \pm 0.08)$ & $+(0.85 \pm 0.05)$ & - & $\begin{array}{l}\text { Leon-Velarde } \\
\text { et al., } 2016\end{array}$ \\
\hline & $14779 / 83$ & $0: 5$ & - & $+(0.34 \pm 0.02)$ & - & - & $\begin{array}{l}\text { Skurnik and } \\
\text { Toivanen, } 1991\end{array}$ \\
\hline & $17223 / 83$ & $0: 5$ & - & $+(0.39 \pm 0.11)$ & - & - & $\begin{array}{l}\text { Leon-Velarde } \\
\text { et al., } 2016\end{array}$ \\
\hline & $18710 / 83$ & O:5 & - & $++(0.77 \pm 0.03)$ & $++(0.70 \pm 0.09)$ & - & $\begin{array}{l}\text { Leon-Velarde } \\
\text { et al., } 2016\end{array}$ \\
\hline & KJP $4209 \mathrm{cr}+$ & O:5 & - & $++(0.62 \pm 0.05)$ & $++(0.75 \pm 0.10)$ & $+(0.63 \pm 0.08)$ & Prpic et al., 1983 \\
\hline & gk7500 & O:5,27 & - & $++(0.65 \pm 0.10)$ & $++(0.67 \pm 0.06)$ & - & $\begin{array}{l}\text { Kapperud et al., } \\
1985\end{array}$ \\
\hline & JD E657 & O:5,27 & - & $++(0.71 \pm 0.05)$ & $++(0.87 \pm 0.08)$ & $+(0.21 \pm 0.09)$ & $\begin{array}{l}\text { Schiemann and } \\
\text { Devenish, } 1982\end{array}$ \\
\hline & JD E654 & O:5,27 & - & $++(0.75 \pm 0.12)$ & $++(0.81 \pm 0.07)$ & - & $\begin{array}{l}\text { Schiemann and } \\
\text { Devenish, } 1982\end{array}$ \\
\hline & gc $815-73$ & O:5,27 & - & $++(0.59 \pm 0.06)$ & $++(0.78 \pm 0.05)$ & $+(0.65 \pm 0.05)$ & Kay et al., 1983 \\
\hline & $\mathrm{A} 2-1$ & O:5,27 & - & $++(0.84 \pm 0.07)$ & $++(0.82 \pm 0.11)$ & $+(0.69 \pm 0.07)$ & Bozcal et al., 2015 \\
\hline & $590 / 80$ & $0: 6$ & $++(0.62 \pm 0.07)$ & $++(0.78 \pm 0.06)$ & - & - & Skurnik, 1984 \\
\hline & $266 / 84$ & O:6 & $+(0.21 \pm 0.09)$ & $+(0.15 \pm 0.07)$ & - & $+(0.11 \pm 0.06)$ & $\begin{array}{l}\text { Leon-Velarde } \\
\text { et al., } 2016\end{array}$ \\
\hline & $189 / 80$ & $0: 6,30$ & - & $+(0.13 \pm 0.08)$ & - & - & Skurnik, 1984 \\
\hline & $6737 / 80$ & $0: 6,30$ & - & $+(0.41 \pm 0.07)$ & - & - & Skurnik, 1984 \\
\hline & $3604 / 80$ & $0: 6,30$ & - & $+(0.44 \pm 0.10)$ & - & - & Skurnik, 1984 \\
\hline & $438 / 80$ & $0: 6,31$ & - & $+(0.63 \pm 0.09)$ & $+(0.79 \pm 0.05)$ & - & Skurnik, 1984 \\
\hline & $1309 / 80$ & $0: 6,31$ & - & $++(0.78 \pm 0.03)$ & $++(0.75 \pm 0.10)$ & $+(0.63 \pm 0.07)$ & Skurnik, 1984 \\
\hline & $22848 / 79$ & O:7,8 & - & $+(0.51 \pm 0.07)$ & $+(0.39 \pm 0.08)$ & - & Skurnik, 1984 \\
\hline & $17869 / 83$ & $0: 7,8$ & - & $+(0.69 \pm 0.11)$ & $+(0.62 \pm 0.09)$ & - & $\begin{array}{l}\text { Leon-Velarde } \\
\text { et al., } 2016\end{array}$ \\
\hline & p310 & $0: 8$ & - & - & - & - & $\begin{array}{l}\text { Leon-Velarde } \\
\text { et al., } 2016\end{array}$ \\
\hline & CDCA2635 & O:8 & - & - & - & $+(0.67 \pm 0.10)$ & $\begin{array}{l}\text { Gemski et al., } \\
1980\end{array}$ \\
\hline & TAMU-75 & $0: 8$ & - & - & - & $+(0.75 \pm 0.09)$ & $\begin{array}{l}\text { Gemski et al., } \\
1980\end{array}$ \\
\hline & WA & $0: 8$ & - & - & - & - & $\begin{array}{l}\text { Gemski et al., } \\
1980\end{array}$ \\
\hline & JD E661 & $0: 8$ & - & - & - & $+(0.61 \pm 0.08)$ & $\begin{array}{l}\text { Schiemann and } \\
\text { Devenish, } 1982\end{array}$ \\
\hline & 8081 & $\mathrm{O}: 8$ & - & - & - & - & $\begin{array}{l}\text { Portnoy et al., } \\
1981\end{array}$ \\
\hline & $8081-\mathrm{R} 2$ & $0: 8$ & - & - & - & - & Zhang et al., 1997 \\
\hline & $8081-c-R 2$ & $\mathrm{O}: 8$ & $+(0.17 \pm 0.07)$ & - & - & - & This study \\
\hline & YeO8-c::WbcEGB & $0: 8$ & - & - & - & - & $\begin{array}{l}\text { Bengoechea et al., } \\
2004\end{array}$ \\
\hline & YeO8:: $\Delta w z z G B$ & O:8 & - & - & - & - & ontinued on next pag \\
\hline
\end{tabular}




\begin{tabular}{|c|c|c|c|c|c|c|c|}
\hline \multirow[t]{2}{*}{ Bacterial species $(n)$} & \multirow[t]{2}{*}{ Strain } & \multirow[t]{2}{*}{ Serotype $^{\mathrm{a}}$} & \multicolumn{4}{|l|}{ Host range $^{\mathrm{b}}\left(\mathrm{EOPs}^{\mathrm{c}}\right)$} & \multirow[t]{2}{*}{ Reference } \\
\hline & & & fHe-Yen3-01 & fHe-Yen9-01 & fHe-Yen9-02 & fHe-Yen9-03 & \\
\hline & & & & & & & $\begin{array}{l}\text { Bengoechea et al., } \\
2004\end{array}$ \\
\hline & YeO8:: $\Delta$ WbcEGB & $0: 8$ & - & - & - & - & $\begin{array}{l}\text { Bengoechea et al., } \\
2004\end{array}$ \\
\hline & $277 / 74$ & $0: 9$ & - & $++(0.77 \pm 0.12)$ & $++(0.61 \pm 0.10)$ & $+(0.17 \pm 0.08)$ & $\begin{array}{l}\text { Leon-Velarde } \\
\text { et al., } 2016\end{array}$ \\
\hline & $4945 / 74$ & O:9 & - & $++(0.79 \pm 0.05)$ & $++(0.75 \pm 0.11)$ & $+(0.52 \pm 0.07)$ & $\begin{array}{l}\text { Leon-Velarde } \\
\text { et al., } 2016\end{array}$ \\
\hline & $767 / 73$ & O:9 & - & $++(0.71 \pm 0.07)$ & $++(0.70 \pm 0.10)$ & $+(0.64 \pm 0.08)$ & $\begin{array}{l}\text { Leon-Velarde } \\
\text { et al., } 2016\end{array}$ \\
\hline & $467 / 73$ & O:9 & - & $++(0.85 \pm 0.11)$ & $++(0.65 \pm 0.09)$ & $+(0.42 \pm 0.09)$ & $\begin{array}{l}\text { Kiljunen et al., } \\
2005 \mathrm{a}\end{array}$ \\
\hline & $3672 / 74$ & O:9 & - & $++(0.70 \pm 0.05)$ & $++(0.71 \pm 0.06)$ & $+(0.74 \pm 0.11)$ & $\begin{array}{l}\text { Leon-Velarde } \\
\text { et al., } 2016\end{array}$ \\
\hline & $13752 / 73$ & $0: 9$ & - & $++(0.71 \pm 0.11)$ & $++(0.75 \pm 0.05)$ & $+(0.82 \pm 0.09)$ & $\begin{array}{l}\text { Leon-Velarde } \\
\text { et al., } 2016\end{array}$ \\
\hline & Ruokola/71-c & O:9 & $++(0.44 \pm 0.08)$ & $++(0.96 \pm 0.05)$ & $++(0.99 \pm 0.07)$ & $+(0.97 \pm 0.05)$ & Skurnik, 1984 \\
\hline & $3102 / 80$ & O:10 & - & $+(0.13 \pm 0.09)$ & - & - & Skurnik, 1984 \\
\hline & $3788 / 80$ & O:10 & - & $+(0.15 \pm 0.07)$ & - & - & $\begin{array}{l}\text { Skurnik et al., } \\
1983\end{array}$ \\
\hline & $2640 / 84$ & $0: 10$ & - & - & - & - & $\begin{array}{l}\text { Leon-Velarde } \\
\text { et al., } 2016\end{array}$ \\
\hline & $10927 / 84$ & O:10 & $+(0.11 \pm 0.07)$ & - & - & - & $\begin{array}{l}\text { Leon-Velarde } \\
\text { et al., } 2016\end{array}$ \\
\hline & gc $1209-79$ & $\mathrm{O}: 13$ & - & - & - & - & Kay et al., 1983 \\
\hline & ST 5081 & $\begin{array}{l}\text { O:13- } \\
a, 13 b\end{array}$ & - & - & - & - & Toma et al., 1984 \\
\hline & $421 / 84$ & O: 13,7 & - & $+(0.07 \pm 0.05)$ & - & - & $\begin{array}{l}\text { Leon-Velarde } \\
\text { et al., } 2016\end{array}$ \\
\hline & $2446 / 84$ & O:13,7 & $+(0.17 \pm 0.10)$ & $+(0.59 \pm 0.11)$ & $+(0.64 \pm 0.09)$ & - & $\begin{array}{l}\text { Leon-Velarde } \\
\text { et al., } 2016\end{array}$ \\
\hline & gc $9312-78$ & O:13,18 & - & - & - & - & Kay et al., 1983 \\
\hline & $15712 / 83$ & $\mathrm{O}: 14$ & $++(0.61 \pm 0.08)$ & $+(0.51 \pm 0.07)$ & - & - & $\begin{array}{l}\text { Skurnik and } \\
\text { Toivonen, } 2011\end{array}$ \\
\hline & gc $874-77$ & O:20 & $+(0.15 \pm 0.08)$ & - & - & - & Kay et al., 1983 \\
\hline & gc $1223-75$ & O:20 & - & - & - & - & Kay et al., 1983 \\
\hline & RB E736 & $0: 21$ & - & - & - & - & $\begin{array}{l}\text { Perry and } \\
\text { Brubaker, } 1983\end{array}$ \\
\hline & WI-81-50 & $0: 21$ & $+(0.40 \pm 0.07)$ & $++(0.72 \pm 0.05)$ & $++(0.81 \pm 0.07)$ & $+(0.24 \pm 0.09)$ & Schiemann, 1984 \\
\hline & 80-EA-63 & $0: 21$ & - & - & - & - & Schiemann, 1984 \\
\hline & $431 / 84$ & $0: 25$ & - & - & - & - & $\begin{array}{l}\text { Skurnik and } \\
\text { Toivonen, } 2011\end{array}$ \\
\hline & $63 / 84$ & O:26,44 & - & $++(0.82 \pm 0.11)$ & $++(0.87 \pm 0.13)$ & - & Skurnik, 1985 \\
\hline & $18425 / 83$ & $\begin{array}{l}O: 25,26,- \\
44\end{array}$ & - & $++(0.61 \pm 0.09)$ & $++(0.62 \pm 0.07)$ & - & Skurnik, 1985 \\
\hline & $5186 / 84$ & $\mathrm{O}: 28,50$ & $+(0.41 \pm 0.07)$ & $+(0.45 \pm 0.11)$ & - & - & Skurnik, 1985 \\
\hline & gc 2139-72 & O:34 & - & - & - & - & Kay et al., 1983 \\
\hline & $248 / 84$ & O:35,52 & $+(0.35 \pm 0.05)$ & $+(0.37 \pm 0.06)$ & - & - & Skurnik, 1985 \\
\hline & $7104 / 83$ & $0: 35,36$ & - & $++(0.73 \pm 0.07)$ & $++(0.67 \pm 0.08)$ & - & Skurnik, 1985 \\
\hline & $264 / 85$ & $0: 41,43$ & - & $++(0.77 \pm 0.10)$ & $++(0.66 \pm 0.09)$ & - & $\begin{array}{l}\text { Skurnik and } \\
\text { Toivonen, } 2011\end{array}$ \\
\hline & $626 / 83$ & $\begin{array}{l}0: 41(27) \\
42\end{array}$ & - & $++(0.81 \pm 0.07)$ & $++(0.75 \pm 0.09)$ & - & $\begin{array}{l}\text { Skurnik and } \\
\text { Toivonen, } 2011\end{array}$ \\
\hline & $9613 / 83$ & $\begin{array}{l}\mathrm{O}: 41(27) \\
\mathrm{K} 1\end{array}$ & - & $+(0.41 \pm 0.05)$ & - & - & $\begin{array}{l}\text { Leon-Velarde } \\
\text { et al., } 2016\end{array}$ \\
\hline & $19942 / 83$ & $\begin{array}{l}\mathrm{O}: 41(27- \\
), 42, \mathrm{~K} 1\end{array}$ & - & $+(0.37 \pm 0.09)$ & - & - & Skurnik, 1985 \\
\hline & $1346 / 84$ & $\begin{array}{l}\text { O: } 41(27- \\
), 43\end{array}$ & - & $++(0.89 \pm 0.11)$ & $++(0.85 \pm 0.09)$ & $++(0.81 \pm 0.08)$ & Skurnik, 1985 \\
\hline & $647 / 83$ & $\begin{array}{l}\text { O:41(27- } \\
), 43\end{array}$ & - & $+(0.93 \pm 0.09)$ & $+(0.92 \pm 0.10)$ & - & Skurnik, 1985 \\
\hline & 3229 & $0: 50$ & - & $+(0.69 \pm 0.12)$ & $+(0.81 \pm 0.09)$ & - & $\begin{array}{l}\text { Skurnik and } \\
\text { Toivanen, } 1991\end{array}$ \\
\hline \multirow[t]{6}{*}{ Y. frederiksenii (6) } & $498 / 85$ & NT & $+(0.37 \pm 0.08)$ & $+(0.53 \pm 0.10)$ & - & - & Reuter et al., 2014 \\
\hline & $28 / 85$ & K1, NT & $+(0.13 \pm 0.07)$ & $+(0.17 \pm 0.08)$ & - & - & Reuter et al., 2014 \\
\hline & IP 23047 & $0: 3$ & $+(0.55 \pm 0.11)$ & - & - & - & $\begin{array}{l}\text { Pajunen et al., } \\
2000\end{array}$ \\
\hline & $3400 / 83$ & $0: 16$ & - & $+(0.57 \pm 0.13)$ & - & - & $\begin{array}{l}\text { Skurnik and } \\
\text { Toivonen, } 2011\end{array}$ \\
\hline & $3317 / 84$ & O:35 & $+(0.39 \pm 0.09)$ & $++(0.84 \pm 0.12)$ & $++(0.89 \pm 0.09)$ & $+(0.51 \pm 0.07)$ & $\begin{array}{l}\text { Skurnik and } \\
\text { Toivonen, } 2011\end{array}$ \\
\hline & $38 / 83$ & $0: 48$ & - & - & - & - & $\begin{array}{l}\text { Skurnik and } \\
\text { Toivonen, } 2011 \\
\text { continued on next page) }\end{array}$ \\
\hline
\end{tabular}


Table 1 (continued)

\begin{tabular}{|c|c|c|c|c|c|c|c|}
\hline \multirow[t]{2}{*}{ Bacterial species $(n)$} & \multirow[t]{2}{*}{ Strain } & \multirow[t]{2}{*}{ Serotype $^{a}$} & \multicolumn{4}{|c|}{ Host range $^{\mathrm{b}}\left(\mathrm{EOPs}^{\mathrm{c}}\right)$} & \multirow[t]{2}{*}{ Reference } \\
\hline & & & fHe-Yen3-01 & fHe-Yen9-01 & fHe-Yen9-02 & fHe-Yen9-03 & \\
\hline \multirow[t]{4}{*}{ Y. kristensenii (4) } & $4336 / 83$ & UT & - & - & - & - & $\begin{array}{l}\text { Leon-Velarde } \\
\text { et al., } 2016\end{array}$ \\
\hline & $19,602 / 83$ & NT & - & - & - & - & $\begin{array}{l}\text { Leon-Velarde } \\
\text { et al., } 2016\end{array}$ \\
\hline & IP 22828 & $0: 3$ & $+(0.54 \pm 0.09)$ & - & - & - & $\begin{array}{l}\text { Pajunen et al., } \\
2000\end{array}$ \\
\hline & $119 / 84$ & $\mathrm{O}: 12,25$ & $+(0.30 \pm 0.11)$ & $+(0.32 \pm 0.10)$ & $+(0.53 \pm 0.09)$ & $+(0.67 \pm 0.12)$ & Skurnik, 1985 \\
\hline Y. pseudotuberculosis & $2812 / 79$ & $\mathrm{O}: 1 \mathrm{~b}$ & - & - & - & - & Skurnik, 1984 \\
\hline \multirow[t]{3}{*}{ (4) } & $677 / 82$ & $0: 1 b$ & - & - & - & - & $\begin{array}{l}\text { Leon-Velarde } \\
\text { et al., } 2016\end{array}$ \\
\hline & $1261 / 79$ & $0: 3$ & - & - & - & - & Skurnik, 1984 \\
\hline & $324 / 80$ & $0: 3$ & - & - & - & - & $\begin{array}{l}\text { Skurnik and } \\
\text { Toivanen, } 1991\end{array}$ \\
\hline \multirow[t]{3}{*}{ Y. bercovieri (3) } & $127 / 84$ & NT & $+(0.41 \pm 0.09)$ & $+(0.51 \pm 0.10)$ & - & $+(0.52 \pm 0.07)$ & $\begin{array}{l}\text { Wauters et al., } \\
1988\end{array}$ \\
\hline & $3016 / 84$ & O:58,16 & $+(0.61 \pm 0.08)$ & $+(0.42 \pm 0.09)$ & - & $+(0.44 \pm 0.07)$ & $\begin{array}{l}\text { Wauters et al., } \\
1988\end{array}$ \\
\hline & $3984 / 84$ & O:58,16 & $+(0.52 \pm 0.10)$ & $+(0.51 \pm 0.07)$ & $+(0.62 \pm 0.07)$ & $+(0.52 \pm 0.05)$ & $\begin{array}{l}\text { Wauters et al., } \\
1988\end{array}$ \\
\hline \multirow[t]{2}{*}{ Y. aleksiciae (2) } & $404 / 81$ & $0: 16$ & - & $+(0.34 \pm 0.07)$ & - & - & $\begin{array}{l}\text { Skurnik and } \\
\text { Toivonen, } 2011\end{array}$ \\
\hline & $317 / 82$ & $0: 16$ & - & $++(0.82 \pm 0.12)$ & $++(0.75 \pm 0.08)$ & - & $\begin{array}{l}\text { Leon-Velarde } \\
\text { et al., } 2016\end{array}$ \\
\hline \multirow[t]{2}{*}{$Y$. intermedia (2) } & $9 / 85$ & O:16,21 & - & - & $+(0.71 \pm 0.07)$ & $+(0.78 \pm 0.10)$ & $\begin{array}{l}\text { Skurnik and } \\
\text { Toivonen, } 2011\end{array}$ \\
\hline & $821 / 84$ & $0: 52,54$ & $+(0.17 \pm 0.07)$ & $+(0.93 \pm 0.10)$ & $+(0.85 \pm 0.09)$ & - & $\begin{array}{l}\text { Skurnik and } \\
\text { Toivanen, } 1991\end{array}$ \\
\hline \multirow[t]{2}{*}{ Y. mollaretii (2) } & IP 22404 & $0: 3$ & $+(0.25 \pm 0.08)$ & - & - & - & $\begin{array}{l}\text { Pajunen et al., } \\
2000\end{array}$ \\
\hline & $92 / 84$ & $\begin{array}{l}0: 59(20,- \\
36,7)\end{array}$ & $+(0.35 \pm 0.08)$ & $+(0.24 \pm 0.05)$ & $+(0.32 \pm 0.10)$ & $+(0.34 \pm 0.09)$ & $\begin{array}{l}\text { Wauters et al., } \\
1988\end{array}$ \\
\hline$Y$. nurmii & DSM 22296 & UT & - & - & - & - & $\begin{array}{l}\text { Murros-Kontiainen } \\
\text { et al., 2011a }\end{array}$ \\
\hline Y. pekkanenii & Å125 KOH2 & UT & - & - & - & - & $\begin{array}{l}\text { Murros-Kontiainen } \\
\text { et al., 2011b-> }\end{array}$ \\
\hline
\end{tabular}

${ }^{\text {a }}$ NT, non-typeable; UT, untyped.

b ++ , clear plaque; + , turbid plaque; - , no plaque.

${ }^{c}$ The EOP (efficiency of plating) values were shown as the mean of observations at three different occasions.

Although several phages able to infect $Y$. enterocolitica have been described, their study has focused only on physiological and/or genomic characterization (Kiljunen et al., 2005a, 2005b; Leon-Velarde et al., 2016; Pajunen et al., 2000, 2001; Schwudke et al., 2008; Skurnik et al., 2012). In the current work, we isolated and characterized a virulent Podoviridae phage, designated fHe-Yen3-01, and three virulent Myoviridae phages, fHe-Yen9-01, fHe-Yen9-02, and fHe-Yen9-03 from a Finnish sewage sample. Furthermore, we generated models of contamination to mimic situations considered to be the sources of human yersiniosis. Our aim was to evaluate the effectiveness of Yersinia phages against $Y$. enterocolitica in pork products and on kitchen utensils.

\section{Materials and methods}

\subsection{Phage isolation and physiological characterization}

\subsubsection{Phage isolation and purification}

Sewage samples were collected from a sewage treatment facility in Viikki, Helsinki, Finland in 2013. Phage isolation was performed using a standard enrichment method with two indicator bacteria, $Y$. enterocolitica O:3 strain 6471/76 and $Y$. enterocolitica O:9 strain Ruokola/ 71 (Skurnik, 1984). All bacterial strains used in this study were cultured in LB broth or on LB agar (LB broth supplemented with $1.5 \%$ agar) at $25^{\circ} \mathrm{C}$ (Table 1). Phage activity was examined using the conventional double-layer agar method (Adams, 1959) with some modifications. A $100-\mu l$ phage suspension was mixed with $300 \mu$ of indicator bacteria.
This phage/bacteria suspension was carefully mixed into molten $\left(50^{\circ} \mathrm{C}\right)$ soft agar, which was then poured onto prepared LB agar. The soft agar was allowed to solidify for $15 \mathrm{~min}$ before the plates were incubated overnight at $25^{\circ} \mathrm{C}$.

Plaque purification was performed as previously described (Salem et al., 2015) and repeated three times to ensure that the phage stocks were derived from single plaques. The phages were stored at $4{ }^{\circ} \mathrm{C}$ in SM buffer (50 mM Tris-HCL [pH 7.5], $0.1 \mathrm{M} \mathrm{NaCl}, 8 \mathrm{mM} \mathrm{MgSO}_{4}$ and $0.01 \%$ $[w / v]$ gelatin).

\subsubsection{Phage morphology, host range, and efficiency of plating (EOP)}

To propagate the Yersinia phages in liquid culture, $50 \mathrm{ml}$ cultures of $Y$. enterocolitica strains $6471 / 76$ or Ruokola/71 in logarithmic phase $\left(\mathrm{OD}_{600} \sim 0.5\right)$ were infected with the phages at MOI of 10 , and incubated shaking for $24 \mathrm{~h}$ at $25^{\circ} \mathrm{C}$. The cultures were then centrifuged for $20 \mathrm{~min}$ at $10,000 \times g$, and the resultant supernatants were passed through $0.45-\mu \mathrm{m}$ membrane filters. This procedure was repeated twice to increase the phage titer. For electron microscopy analysis, the phage suspension was purified using Amicon ${ }^{\circledast}$ Ultra centrifugal filter units (MWCO $100 \mathrm{kDa}$ ) according to the supplier's instructions (SigmaAldrich, St. Louis, MO, USA). The purified phages $\left(10^{9}\right.$ plaque-forming units $[\mathrm{PFU}] / \mathrm{ml}$ of each phage) were negatively stained with $2 \%$ uranyl acetate, and electron micrographs were taken using JEM 1010 (JEOL, Tokyo, Japan) and JEM 1400 (JEOL) transmission electron microscopes at an accelerating voltage of $80 \mathrm{kV}$. Average phage size was determined from 6 to 8 independent measurements. 
To evaluate phage host range, the infectivity of the purified phages $\left(10^{9} \mathrm{PFU} / \mathrm{ml}\right)$ was tested on 106 Yersinia strains, with plaque formation and number being determined after $24 \mathrm{~h}$ of incubation. Plaques were classified into the following three categories according to the degree of clarity: clear, turbid, and no reaction. PFU measurements were taken using the double-layer agar method. The ratio of the number of PFUs obtained with each phage-susceptible strain to the number of those obtained with the corresponding indicator strain was then calculated to obtain EOP values. The EOP assay was performed in triplicate.

\subsubsection{One-step growth curve and growth curves of phage-infected bacteria}

One-step growth curve analyses were performed as previously described (Ellis and Delbruck, 1939) to determine the burst sizes and latent periods of the phages. The bacterial cultures in the mid-exponential phase were adjusted to approximately $2-7 \times 10^{7}$ colony-forming units (CFU)/ml for strains $6471 / 76$ and Ruokola/71. Phage was added to $30 \mathrm{ml}$ of bacterial cultures to achieve a multiplicity of infection (MOI) of 0.001 . The preparations were incubated at $25^{\circ} \mathrm{C}$ with shaking at $200 \mathrm{rpm}$. Every $5 \mathrm{~min}, 10 \mu \mathrm{l}$ was collected and titrated by the doublelayer agar method.

The growth curves for $Y$. enterocolitica O:3 strain 6471/76 and $Y$. enterocolitica O:9 strain Ruokola/71 infected by the four phages were determined. Overnight culture of bacteria were diluted 1:20 and grown for $1 \mathrm{~h}$ at $25^{\circ} \mathrm{C}$ to reach early-exponential phase $\left(\mathrm{OD}_{600} \sim 0.5\right)$, and the cultures were divided into $161-\mathrm{ml}$ aliquots and infected with the phage at MOIs of $0.1,1$, and 10, after which the total volume of the cultures was adjusted to $30 \mathrm{ml}$. Non-infected bacteria were used as a control. The cultures were incubated at $25^{\circ} \mathrm{C}$ with shaking at $200 \mathrm{rpm}$, and the $\mathrm{OD}_{600}$ was monitored for $24 \mathrm{~h}$ in order to determine changes in the number of viable bacteria throughout the incubation period.

\subsubsection{Stability test}

Phage stability tests were carried out as previously described (Jun et al., 2014b). Briefly, to examine phage stability in organic solvents, each phage solution $\left(10^{4} \mathrm{PFU} / \mathrm{ml}\right)$ was mixed with an equal volume of chloroform, ethanol, or ether, and incubated at $25^{\circ} \mathrm{C}$ for $1 \mathrm{~h}$. To evaluate the stability of phages at different $\mathrm{pH}$ values, each phage suspension (at a final concentration of $10^{4} \mathrm{PFU} / \mathrm{ml}$ ) was inoculated into $\mathrm{LB}$ broth adjusted to a $\mathrm{pH}$ of $3,5,7,9$, or 11 using $1 \mathrm{M} \mathrm{HCl}$ or $1 \mathrm{M} \mathrm{NaOH}$ and incubated at $25^{\circ} \mathrm{C}$ for $1 \mathrm{~h}$. Phage suspensions maintained at $\mathrm{pH} 7$ served as controls. Stability at different temperatures was determined by incubating $10^{4} \mathrm{PFU} / \mathrm{ml}$ of each phage at $4,20,25,30,37,50$, or $65^{\circ} \mathrm{C}$ for $1 \mathrm{~h}$. Following exposure to each condition, the phage suspensions were titrated by the double-layer agar method. All tests were repeated three times.

The logarithmic reduction factor was calculated as an estimate of phage survival in each stability test, as follows:

$\mathrm{R}=\log \mathrm{A}_{\mathrm{con}}-\log \mathrm{A}_{\text {exp }}$

where $\mathrm{R}$ is the reduction factor, $\mathrm{A}_{\text {con }}$ is the phage titer of the control, and $A_{\exp }$ is the phage titer after exposure to a particular organic solvent, $\mathrm{pH}$, or temperature.

\subsection{Phage genome characterization}

\subsubsection{Genome sequencing and assembly}

Phage genomic DNA was extracted from $2 \mathrm{ml}$ of purified phage suspension $\left(10^{9} \mathrm{PFU} / \mathrm{ml}\right)$ as previously described (Sambrook et al., 1989). Purified phage particles were treated with $10 \%$ SDS and proteinase $\mathrm{K}$, and their DNA was extracted with phenol:chloroform:isoamyl alcohol and ethanol precipitation. Sequencing was performed at the Institute for Molecular Medicine Finland (FIMM) Technology Centre Sequencing Unit (https://www.fimm.fi/en/services/technologycentre/). The DNA library was constructed with a Nextera sample preparation kit (Illumina, San Diego, CA, USA), and paired-end sequencing was carried out using a MiSeq PE300 sequencer (Illumina) with a read length of 300 nucleotides. The A5-miseq integrated pipeline for de novo assembly of microbial genomes was used to assemble the genomic sequences (Coil et al., 2015). The fHe-Yen3-01 and fHe-Yen901 sequence data consisted of 80,794 and 43,776 reads, providing 384 and 80 -fold coverage, respectively.

\subsubsection{Bioinformatics and phylogeny}

The genomic sequences of the phages were analyzed for putative genes using the GLIMMER and GeneMarkS software (Besemer et al., 2001; Delcher et al., 1999). All the predicted genes encoding products longer than 30 amino acids were taken into consideration. Final annotation of the sequences was performed manually and the sequences were submitted to GenBank using the Sequin program. Global genome sequence alignments were carried out using the EMBOSS stretcher program. The BLASTP search tool provided by the National Center for Biotechnology Information was used to search for homologs of the predicted gene products. Transmembrane domains and signal sequences were predicted with the programs TMHMM ver. 2.0 and SignalP 4.0 (Krogh et al., 2001; Petersen et al., 2011). Molecular weight and pI were predicted using the proteomics tools on the ExPASy server. Virulence factor searching was carried out using Virulence Factors of Pathogenic Bacteria (http://www.mgc.ac.cn/VFs/main.htm). Phage genome maps were created using DNA Master. The genomic sequences of fHe-Yen3-01 and fHe-Yen9-01 were deposited to the GenBank database under the accession numbers KY318515 and KY593455, respectively.

Phylogeny analysis was conducted using the VICTOR Virus Classification and Tree Building Online Resource (Meier-Kolthoff and Göker, 2017) that employed the Genome-BLAST Distance Phylogeny (GBDP) method (Meier-Kolthoff et al., 2013) under settings recommended for prokaryotic viruses (Meier-Kolthoff and Göker, 2017). The resulting intergenomic distances (including 100 replicates each) were used to predict a balanced minimum evolution tree with branch support via FASTME including Subtree Pruning and Regrafting (SPR) postprocessing (Lefort et al., 2015) for the formula D0. The tree was rooted at the midpoint (Farris, 1972) and visualized using FigTree (http://tree.bio.ed.ac.uk/software/figtree/). Taxon boundaries at the species, genus, and family level were estimated using the OPTSIL program (Göker et al., 2009), the recommended clustering thresholds (Meier-Kolthoff and Göker, 2017), and an F value (fraction of links required for cluster fusion) of 0.5 (Meier-Kolthoff et al., 2014).

\subsection{Artificial contamination and application of phages to foods and kitchen utensils}

\subsubsection{Food samples}

Raw minced pork, ready-to-eat (RTE) barbequed pork loin (approximately $5 \times 8 \mathrm{~cm}$ ) cut into 2 -mm thick chops or slices, and milk were purchased from grocery stores. The food samples were cultured on the Yersinia-selective Cefsulodin-irgasan-novobiocin (CIN) agar (Oxoid, Cambridge, UK) to detect possible background contamination with Yersinia spp.. Immediately after the purchase, the pork samples were aseptically distributed in 25-g portions on Petri dishes, and milk, in $25 \mathrm{ml}$ aliquots into conical tubes. These were then divided into phage-treated and un-treated groups and used without delay in the experiments.

\subsubsection{Kitchen utensils and artificial hands}

Cutting boards of two different materials (wood and plastic) and knives were purchased and sterilized using ethylene oxide. Sterile surgical gloves were put on the artificial hands, constructed of wood and plastic, in a biosafety level-2 laminar flow hood while wearing sterile surgical gloves. 


\subsubsection{Bacterial contamination and phage application}

Bacterial inoculation was performed as previously described (Jun et al., 2014a), with some modifications. Kitchen utensils and artificial hands were placed horizontally to prevent the bacterial and phage suspensions to run out from their surfaces, and divided into humid and dry condition groups.

$Y$. enterocolitica 0:9 strain Ruokola/71 was grown to early-exponential phase $\left(\mathrm{OD}_{600} \sim 0.5\right)$, diluted to $\sim 10^{4} \mathrm{CFU} / \mathrm{ml}$, and $1 \mathrm{ml}$ of this suspension was used to contaminate the food samples to reach an approximate bacterial inoculation level of $10^{3} \mathrm{CFU} / \mathrm{g}$ or $\mathrm{ml}$. To distribute the bacteria uniformly, the inoculated minced pork and milk samples were mixed thoroughly, and the bacterial suspension was uniformly spread onto the surface of the sliced RTE pork. To enable bacterial cells to bind to the food, the inoculated samples were air-dried for $15 \mathrm{~min}$ in a biosafety level-2 laminar flow hood. For the phage-treated groups, raw pork and milk were treated with $1 \mathrm{ml}$ of phage and mixed thoroughly to yield a final dose of $1.77 \times 10^{8} \mathrm{PFU} / \mathrm{g}$ and $1.98 \times 10^{8} \mathrm{PFU} /$ $\mathrm{ml}$, respectively, while the phage solution was uniformly spread on the surface of the RTE pork to yield a final dose of $1.82 \times 10^{8} \mathrm{PFU} / \mathrm{g}$. For the non-treated controls $1 \mathrm{ml}$ of sterile saline was applied to the samples. Once treated, the raw pork and milk samples were maintained at $4{ }^{\circ} \mathrm{C}$ up to $72 \mathrm{~h}$ and the RTE pork was kept in a biosafety level-2 laminar flow hood at $26 \pm 1{ }^{\circ} \mathrm{C}$ for up to $12 \mathrm{~h}$. At appropriate time points, samples were withdrawn for determinations of CFU and PFU.

To inoculate kitchen utensils and artificial hands, $1 \mathrm{ml}$ of the bacterial suspension (ca. $10^{6} \mathrm{CFU} / \mathrm{ml}$ ) was uniformly spread across an equivalent area $(10 \mathrm{~cm} \times 10 \mathrm{~cm}$ on cutting boards, one side for knives and artificial hands) in both humid and dry groups. This resulted in viable counts of $6.35 \times 10^{3} \mathrm{CFU} / \mathrm{cm}^{2}$ on the wooden cutting boards, $3.35 \times 10^{3} \mathrm{CFU} / \mathrm{cm}^{2}$ on the plastic cutting boards, $4.65 \times 10^{3} \mathrm{CFU} / \mathrm{ml}$ on the knives, and $1.3 \times 10^{3} \mathrm{CFU} / \mathrm{ml}$ on the artificial hands. After airdrying the samples for $15 \mathrm{~min}, 1 \mathrm{ml}$ of phage suspension (ca. $10^{11} \mathrm{PFU}$ / $\mathrm{ml}$ ) was applied uniformly across the inoculated area. Sampling the utensils immediately after phage application yielded counts of $2.3 \times 10^{8} \mathrm{PFU} / \mathrm{cm}^{2}$ on wooden cutting boards, $2.35 \times 10^{8} \mathrm{PFU} / \mathrm{cm}^{2}$ on plastic cutting boards, $2.25 \times 10^{8} \mathrm{PFU} / \mathrm{ml}$ on knives, and $2.9 \times 10^{8} \mathrm{PFU} / \mathrm{ml}$ on artificial hands. The samples in the dry group were kept in a biosafety level-2 laminar flow hood, while those in the humid group were kept in a separate hood with a humidifier (relative humidity, $81 \pm 3 \%$ ).

2.3.4. Quantitative analysis of $Y$. enterocolitica and phages in foods, on kitchen utensils and artificial hands

CFU and PFU counts were performed as previously described (Jun et al., 2014a, 2014b), with several modifications. Samples (25 g) of raw and RTE pork were randomly taken from each group at appropriate time intervals and placed in Petri dishes. They were then homogenized in $225 \mathrm{ml}$ of PMB broth (phosphate-buffered saline with $0.5 \%$ peptone, $1 \%$ mannitol, and $0.15 \%$ bile salts) (Laukkanen et al., 2010) and blended in a Stomacher 400C homogenizer (Seward Limited, Worthing, UK). To determine the CFU and PFU counts, 100- $\mu$ l aliquots of the homogenized samples and milk samples were directly used. The bacteria and phages on kitchen utensil and artificial hand surfaces were sampled using sterile cotton-wool swabs that were vortexed into $1 \mathrm{ml}$ of PMB broth. Similarly, to determine the CFU and PFU counts, 100- $\mu 1$ aliquots of the suspension were used. Cefsulodin-irgasan-novobiocin (CIN) agar (Oxoid, Cambridge, UK) was used to selectively isolate Yersinia for enumeration. During quantification, to confirm the specific isolation of $Y$. enterocolitica, we randomly collected bull's-eye colonies from CIN agar, carried out ail specific PCR (Salem et al., 2015), and checked their antibiotic susceptibility profiles with 12 antibiotics. Phage titers were determined by the double-layer agar method. Bacterial and phage counts were normalized by weight (pork), volume (milk, knives, and artificial hands), or size (cutting boards). The experiment was repeated two times.

\subsection{Phage safety assessment in mice}

\subsubsection{Ethics statement}

Six-week-old specific-pathogen-free female BALB/c mice were used with the approval of the Institutional Animal Care and Use Committee, Seoul National University, Seoul, Republic of Korea (Reg. No. SNU170417-7). All animal care and experimental protocols were performed according to the guidelines of the Animal Ethical Committee, Seoul National University.

\subsubsection{Phage administration safety test}

An in vivo phage safety test was performed with phage fHe-Yen9-01 as previously described (Mai et al., 2015), with several modifications. The experiment involved five groups of six mice. One was a control group without any intervention, the second received $100 \mu \mathrm{l}$ of distilled water, and the other three groups were treated with 100- $\mu$ l volumes of different phage preparations, intragastrically (i.g.), using a 20-gauge stainless-steel ball-tipped catheter. The phage was given as a highly purified preparation (ultra-centrifuged and dialyzed to remove any impurities), as a crude (centrifuged and sterile-filtered) phage lysate, and as a heat-inactivated- $\left(65^{\circ} \mathrm{C}\right.$ for $\left.2 \mathrm{~h}\right)$ phage lysate. The highly purified phage preparation had a titer of $\sim 10^{12} \mathrm{PFU} / \mathrm{ml}$, while that of the crude lysate was $\sim 10^{10} \mathrm{PFU} / \mathrm{ml}$. The health of the mice was then monitored for 28 days.

\subsection{Statistical analysis}

The results were tested for statistically significant differences using Student's $t$-test (unpaired, two-tailed, and homoscedastic). The SPSS statistical software package, version 19.0 (IBM Corp., Armonk, NY, USA) was used for all statistical analyses.

\section{Results}

\subsection{Phage isolation and physiological characterization}

A total of 17 Yersinia phages capable of infecting Y. enterocolitica were isolated from the sewage sample. Of the isolated phages, four (fHe-Yen3-01, fHe-Yen9-01, fHe-Yen9-02, and fHe-Yen9-03) were selected for further study owing to the clarity of the plaques that they formed. Electron microscopy revealed that fHe-Yen3-01 had an icosahedral head and short tail, and fHe-Yen9-01, fHe-Yen9-02, and fHeYen9-03 each had a prolate head with icosahedral symmetry and a contractile tail (Fig. 1). The head diameters of these phages were $44 \pm 4 \mathrm{~nm}$ (mean \pm standard deviation) $(n=6), 69 \pm 9 \mathrm{~nm}(n=8)$, $68 \pm 9 \mathrm{~nm}(n=8)$, and $78 \pm 12 \mathrm{~nm}(n=8)$, respectively; the tail dimensions (length $\times$ width) were $19 \pm 3 \mathrm{~nm} \times 11 \pm 5 \mathrm{~nm}(n=6)$, $116 \pm 5 \mathrm{~nm} \times 24 \pm 6 \mathrm{~nm} \quad(n=8), \quad 125 \pm 11 \mathrm{~nm} \times 27 \pm 4 \mathrm{~nm}$ $(n=8)$, and $104 \pm 11 \mathrm{~nm} \times 19 \pm 3 \mathrm{~nm}(n=8)$, respectively. These morphological features demonstrate that fHe-Yen3-01 belongs to the Podoviridae family and fHe-Yen9-01, fHe-Yen9-02, and fHe-Yen9-03 belong to the Myoviridae family.

The host ranges of the four phages were determined by their ability to infect 10 Yersinia species: Y. enterocolitica $(n=81), Y$. frederiksenii $(n=6), Y$. kristensenii $(n=4), Y$. pseudotuberculosis $(n=4), Y$. bercovieri $(n=3), Y$. aleksiciae $(n=2), Y$. intermedia $(n=2), Y$. mollaretii $(n=2), Y$. nurmii $(n=1)$, and $Y$. pekkanenii $(n=1)$. Of the four phages, fHe-Yen9-01 had the broadest host range, infecting 61.3\% (65/106) of the Yersinia strains used in this study (Table 1), and formed plaques on $65.4 \%(53 / 81)$ of the $Y$. enterocolitica strains tested. fHe-Yen9-02 exhibited the second broadest host range $(42.5 \%, 45 / 106)$, followed by fHe-Yen3-01 (29.2\%, 31/106), and fHe-Yen9-03 (25.5\%, 27/106). High EOP values were noted using strains of several Yersinia species, including $Y$. enterocolitica, $Y$. frederiksenii, $Y$. aleksiciae, and $Y$. intermedia, although the highest EOP values were recorded in relation to the indicator strains (Table 1). None of the $Y$. pseudotuberculosis, Y. nurmii, 


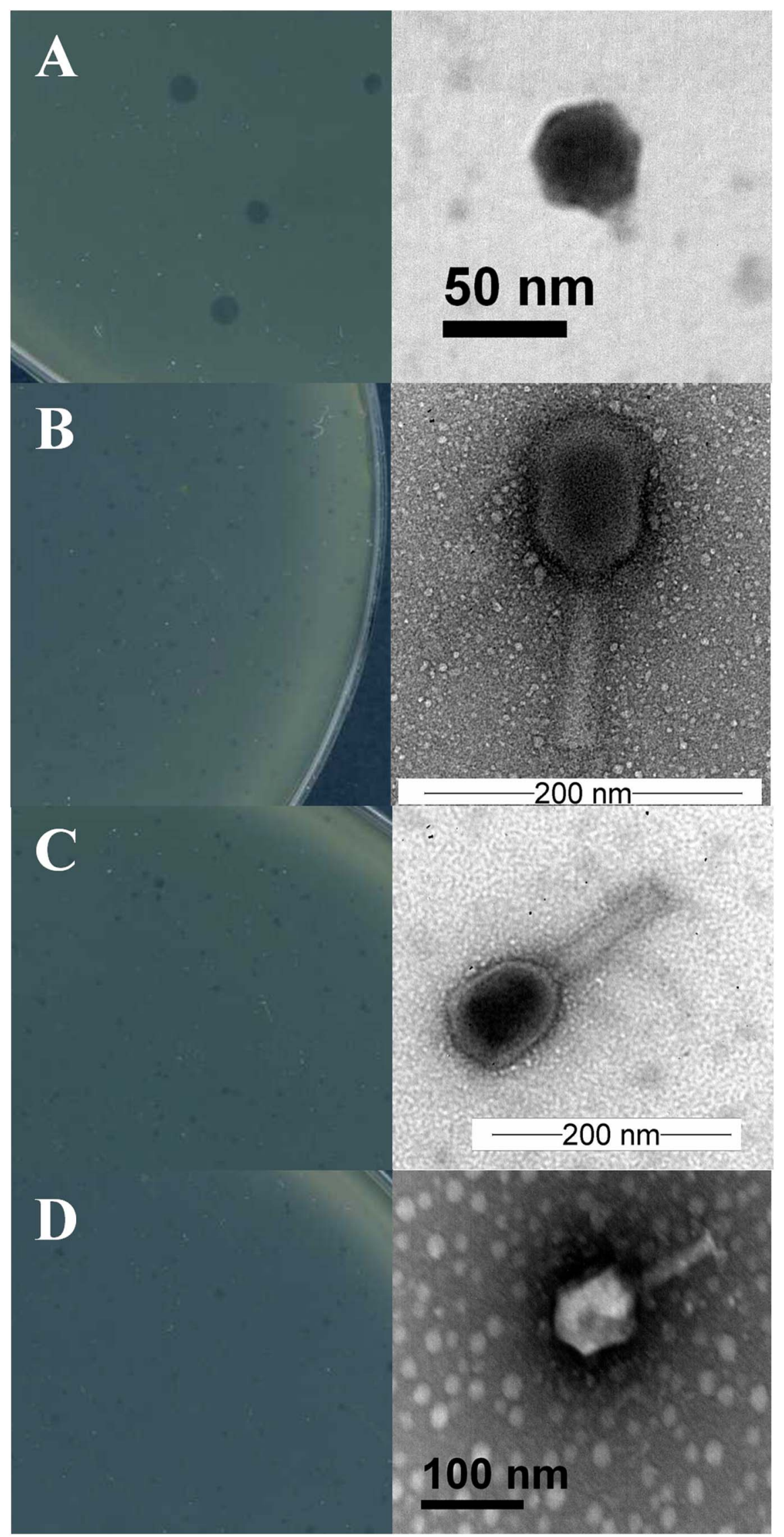

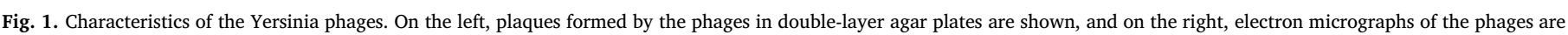
shown. (A) fHe-Yen3-01 (bar = $50 \mathrm{~nm})$, (B) fHe-Yen9-01 (bar = $200 \mathrm{~nm}$ ), (C) fHe-Yen9-02 (bar = $200 \mathrm{~nm})$, and (D) fHe-Yen9-03 (bar $=100 \mathrm{~nm})$. 
and $Y$. pekkanenii strains were infected by any of the four phages.

The one-step growth curves for fHe-Yen3-01, fHe-Yen9-01, fHeYen9-02, and fHe-Yen9-03 revealed latent periods of approximately 40, 35,30 , and $40 \mathrm{~min}$, respectively, and burst sizes of $21,33,20$, and $20 \mathrm{PFU} /$ cell, respectively (Fig. 2). The bacteriolytic effect of the four phages was tested on early-exponential phase cultures of each host strain (Fig. 3). The $\mathrm{OD}_{600}$ of the uninfected control culture (MOI of 0 ) continued to increase during the incubation period. However, the growth of bacteria infected by fHe-Yen9-01 or fHe-Yen9-02 at MOIs of $0.1,1$, and 10 was retarded during the $24 \mathrm{~h}$ of incubation. Significant inhibition of growth was observed at MOIs of 1 and 10, although the bacteriolytic activity of fHe-Yen9-01 or fHe-Yen9-02 was less pronounced at an MOI of 0.1. The bacteriolytic effects of fHe-Yen3-01 and fHe-Yen9-03 differed somewhat from those of fHe-Yen9-01 and fHeYen9-02. Infection with fHe-Yen3-01 at an MOI of 10 inhibited bacterial growth until $18 \mathrm{~h}$, but the $\mathrm{OD}_{600}$ increased thereafter at every MOI, and fHe-Yen9-03 did not effectively inhibit bacterial growth, regardless of MOI.

To evaluate their stability, the four phages were exposed to various conditions. fHe-Yen3-01 was found to be the most sensitive to organic solvents (Table 2). Of the four phages, fHe-Yen9-01 exhibited the smallest decrease in activity following chloroform and ether treatment, with reduction factors (R) of 0.003 and 0.001 , respectively. fHe-Yen903 was the most stable phage with respect to ethanol exposure ( $R=0.091$ ). fHe-Yen9-01 was stable across a pH range of $5-9$, whereas fHe-Yen3-01 and fHe-Yen9-02 were found to be stable under alkaline ( $R=0.875$ at $\mathrm{pH} 11)$ and acidic $(R=0.021$ at $\mathrm{pH} 5)$ conditions, respectively. fHe-Yen9-03 was stable at every $\mathrm{pH}$ tested, from 3 to 11 . The four phages were stable for $1 \mathrm{~h}$ at temperatures from 4 to $37^{\circ} \mathrm{C}$, but significant reductions in activity were observed following exposure to $50^{\circ} \mathrm{C}$. fHe-Yen9-03 was the most stable of the phages tested at this temperature $(R=0.255)$. Incubation of the phages at $65^{\circ} \mathrm{C}$ led to lower levels of activity than those observed after incubation at $50^{\circ} \mathrm{C}$.

A

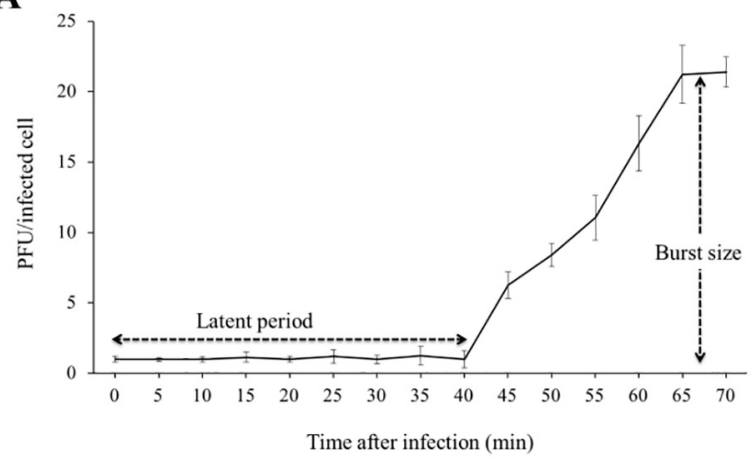

C

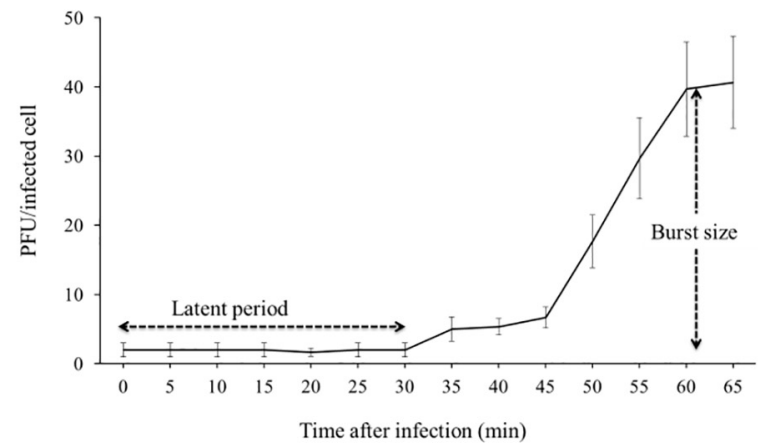

\subsection{Phage genome characterization}

Sequencing revealed the genomes of fHe-Yen3-01 and fHe-Yen9-01 to be 42,771 and 167,773 bp in length, with 47.67 and $34.79 \%$ total GC content, respectively. The predominant start codon was ATG in the genomes of both phages. Several ORFs starting with the alternative start codon (GTG) were found: orf10, orf32, and orf36 (fHe-Yen3-01); and orf42, orf68, orf82, orf85, orf103, and orf148 (fHe-Yen9-01). More details of the predicted genes and gene products, such as locations, directions, sizes, molecular weights, and predicted functions, are shown in Supplementary Table S1.

In the genome of fHe-Yen3-01, 56 genes were identified, and based on similarity searches, functions could be predicted only for 19 of them. The functions of the other genes remain unknown. The 19 gene products (Gps) were categorized into five functional groups: (i) 7 Gps were classified as phage structure and packaging proteins; (ii) 7 as DNA replication and modification proteins; (iii) 1 as signal transduction and regulatory protein; (iv) 2 as nucleotide metabolism proteins; and (v) 2 as host lysis proteins. The genes predicted to encode structural proteins are located between genes $g 41$ and $g 49$. A phylogenetic tree was generated with most closely related phage sequences present in nucleotide databases (Fig. 4A), and the highest similarity was found between fHe-Yen3-01 and the virulent Yersinia phage $\phi 80-18$ [GenBank accession number: HE956710]. $\phi 80-18$ infects $Y$. enterocolitica serotypes 0:7,8 and 0:8 using the LPS O-antigen as receptor (Zhang and Skurnik, 1994; Zhang et al., 1997). The nucleotide sequence identity between fHe-Yen3-01 and $\phi 80-18$ genomes was approximately $93 \%$, with $52(92.85 \%)$ of the former's 56 genes having homologs in the genome of the latter (Fig. 5). Based on the ICTV criteria, these two phages represent separate phage species. It is remarkable, that the host range of $\phi 80-18$ is restricted mainly to $Y$. enterocolitica serotypes $\mathrm{O}: 7,8$ and $\mathrm{O}: 8$, while that of fHe-Yen3-01 is much wider, including many different $Y$. enterocolitica serotype strains and also $Y$. enterocolitica-like species (Table 1). To study whether this host range difference could be

B

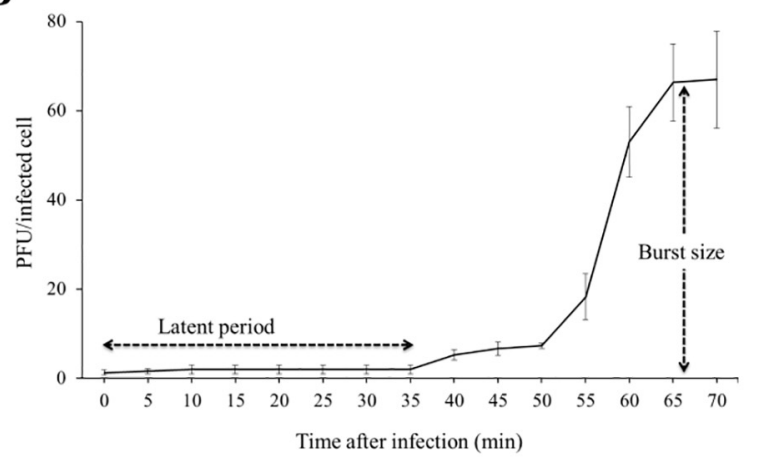

D

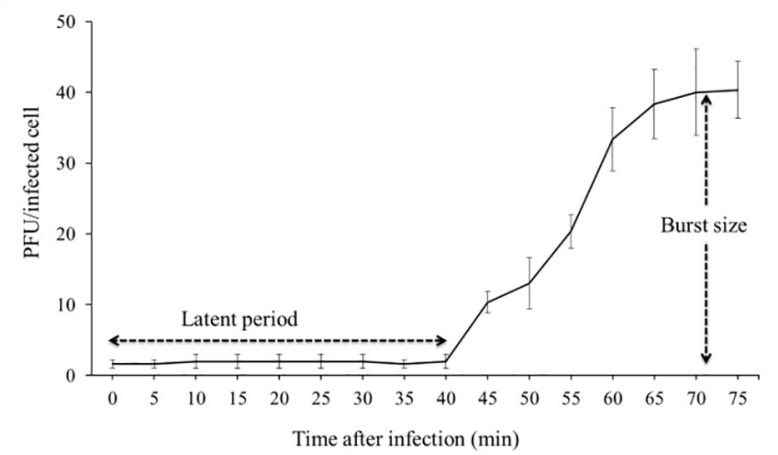

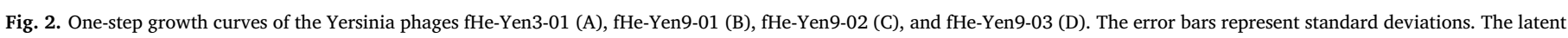
periods and the burst sizes are indicated. 
$\mathbf{A}$

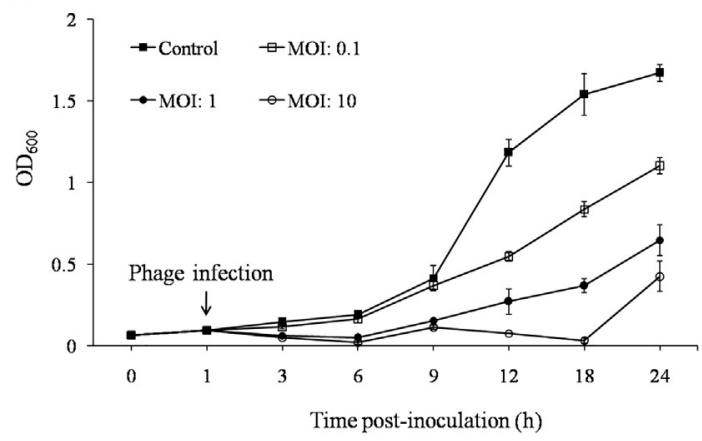

C

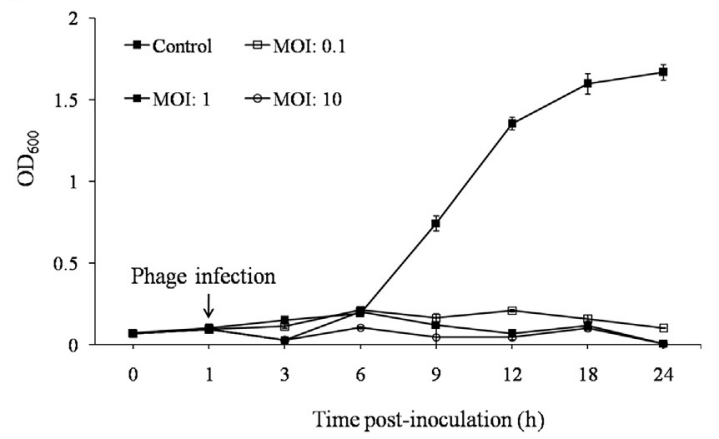

B

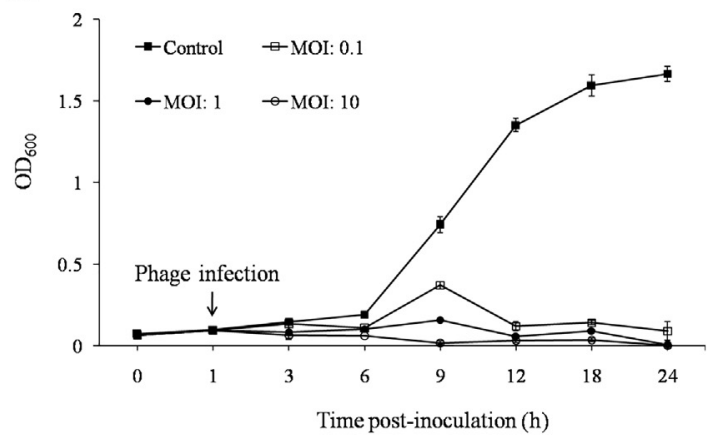

D

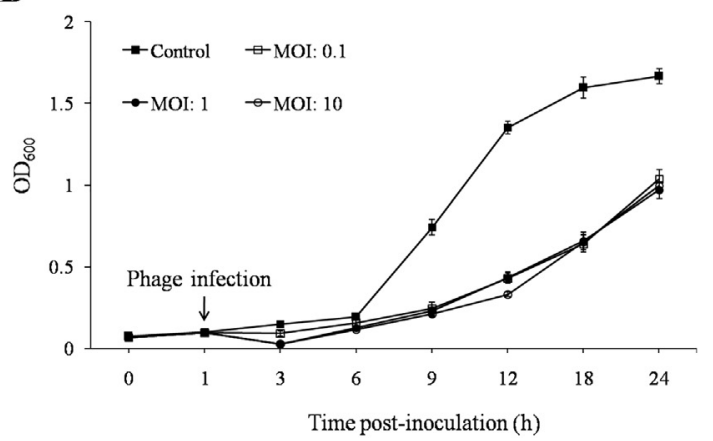

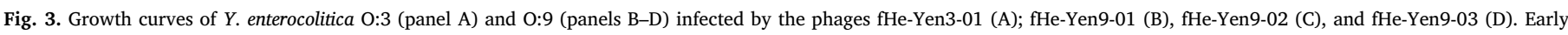

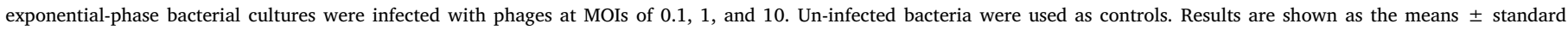
deviations from triplicate experiments.

explained by differences between the receptor binding proteins of these phages, the tail fiber protein sequences of fHe-Yen3-01 (gp49) and $\phi 80-18$ (Gp50) were compared. While they were $82 \%$ identical, 420 amino acids at the $\mathrm{N}$-terminal share $97.5 \%$ identity, and the differences are accumulated within the C-terminal, which occupies one third of the protein and shares only $56 \%$ identity. This is generally the location of the receptor binding domain, thus explaining the differences in the host ranges.

Of the 281 predicted genes in the genome of fHe-Yen9-01, only 114
(40.21\%) could be assigned a putative function. These Gps of the 114 genes represented five functional groups: (i) 49 structural and packaging proteins; (ii) 31 nucleic acid replication and modification proteins; (iii) 11 signal transduction and regulatory proteins; (iv) 16 nucleotide metabolism proteins; and (v) 7 host lysis proteins. fHe-Yen9-01 was found to be closely related to the Yersinia phages vB_YenM_TG1 [KP202158] and vB_YenM_ $\phi R 1-R T$ [HE956709] (Leon-Velarde et al., 2016). Of the 47 structural protein-encoding genes, 35 were located

Table 2

Stability of four Yersinia phages, fHe-Yen3-01, fHe-Yen9-01, fHe-Yen9-02, and fHe-Yen9-03, when exposed to various organic solvents, pH values, and temperatures.

\begin{tabular}{|c|c|c|c|c|}
\hline \multirow{2}{*}{$\begin{array}{l}\text { Experimental } \\
\text { condition }^{\mathrm{a}}\end{array}$} & \multicolumn{4}{|l|}{ Surviving phage ${ }^{\mathrm{b}}$ (reduction factor) } \\
\hline & fHe-Yen3-01 & fHe-Yen9-01 & fHe-Yen9-02 & fHe-Yen9-03 \\
\hline \multicolumn{5}{|l|}{ Organic solvent } \\
\hline PBS (control) & $6.0 \times 10^{4}$ & $1.1 \times 10^{4}$ & $2.6 \times 10^{4}$ & $2.96 \times 10^{4}$ \\
\hline Chloroform & $7.58 \times 10^{3} \pm 1.39 \times 10^{3}(0.899)$ & $1.09 \times 10^{4} \pm 9.1 \times 10^{2}(0.003)$ & $8.6 \times 10^{3} \pm 1.38 \times 10^{3}(0.48)$ & $7.99 \times 10^{3} \pm 5.01 \times 10^{2}(0.569)$ \\
\hline Diethylether & $9.7 \times 10^{3} \pm 2.1 \times 10^{3}(0.792)$ & $1.09 \times 10^{4} \pm 5.25 \times 10^{2}(0.001)$ & $8.25 \times 10^{3} \pm 8.82 \times 10^{2}(0.498)$ & $2.14 \times 10^{4} \pm 1.13 \times 10^{3}(0.141)$ \\
\hline Ethanol & $1.26 \times 10^{4} \pm 1.76 \times 10^{3}(0.676)$ & $4.59 \times 10^{3} \pm 3.1 \times 10^{2}(0.379)$ & $9.94 \times 10^{3} \pm 5.84 \times 10^{2}(0.417)$ & $2.39 \times 10^{4} \pm 1.7 \times 10^{3}(0.091)$ \\
\hline \multicolumn{5}{|c|}{ 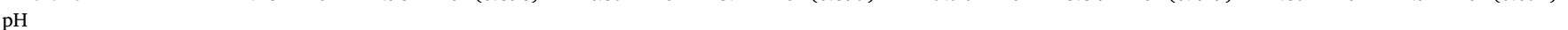 } \\
\hline 3 & $0(4.778)$ & $0(4.041)$ & $0(4.414)$ & $6.41 \times 10^{2} \pm 2.96 \times 10^{2}(1.665)$ \\
\hline 5 & $0(4.778)$ & $8.66 \times 10^{3} \pm 4.37 \times 10^{2}(0.104)$ & $2.47 \times 10^{4} \pm 5.85 \times 10^{2}(0.021)$ & $1.28 \times 10^{4} \pm 1.88 \times 10^{3}(0.361)$ \\
\hline 7 (control) & $6.0 \times 10^{4}$ & $1.1 \times 10^{4}$ & $2.6 \times 10^{4}$ & $2.96 \times 10^{4}$ \\
\hline 9 & $4.27 \times 10^{4} \pm 3.77 \times 10^{3}(0.147)$ & $8.9 \times 10^{3} \pm 9.43 \times 10^{2}(0.092)$ & $6.36 \times 10^{3} \pm 8.87 \times 10^{2}(0.611)$ & $7.61 \times 10^{3} \pm 1.11 \times 10^{3}(0.59)$ \\
\hline 11 & $8.0 \times 10^{3} \pm 6.06 \times 10^{2}(0.875)$ & $0(4.041)$ & $0(4.414)$ & $8.28 \times 10^{2} \pm 4.0 \times 10^{2}(1.553)$ \\
\hline \multicolumn{5}{|l|}{ Temperature } \\
\hline 4 (control) & $6.0 \times 10^{4}$ & $1.1 \times 10^{4}$ & $2.6 \times 10^{4}$ & $2.96 \times 10^{4}$ \\
\hline 20 & $6.04 \times 10^{4} \pm 7.31 \times 10^{2}(-0.003)$ & $1.1 \times 10^{4} \pm 9.3 \times 10(-0.002)$ & $2.61 \times 10^{4} \pm 2.7 \times 10^{2}(-0.003)$ & $2.96 \times 10^{4} \pm 8.4 \times 10^{2}(0)$ \\
\hline 25 & $6.0 \times 10^{4} \pm 2.03 \times 10^{2}(0)$ & $1.1 \times 10^{4} \pm 9.0 \times 10(-0.002)$ & $2.6 \times 10^{4} \pm 1.17 \times 10^{2}(-0.001)$ & $2.95 \times 10^{4} \pm 1.31 \times 10^{2}(0.001)$ \\
\hline 30 & $6.0 \times 10^{4} \pm 8.8 \times 10(0)$ & $1.1 \times 10^{4} \pm 1.25 \times 10^{2}(-0.003)$ & $2.59 \times 10^{4} \pm 1.24 \times 10^{3}(0.001)$ & $2.93 \times 10^{4} \pm 5.0 \times 10(0.005)$ \\
\hline 37 & $5.35 \times 10^{4} \pm 6.1 \times 10^{3}(0.05)$ & $1.11 \times 10^{4} \pm 2.53 \times 10^{2}(-0.005)$ & $2.58 \times 10^{4} \pm 2.15 \times 10^{3}(0.002)$ & $2.64 \times 10^{4} \pm 1.84 \times 10^{3}(0.05)$ \\
\hline 50 & $2.42 \times 10^{3} \pm 1.43 \times 10^{3}(1.395)$ & $1.13 \times 10^{3} \pm 4.82 \times 10^{2}(0.987)$ & $7.71 \times 10^{3} \pm 1.68 \times 10^{3}(0.527)$ & $1.64 \times 10^{4} \pm 4.33 \times 10^{3}(0.255)$ \\
\hline 65 & $0(4.778)$ & $0(4.041)$ & $0(4.414)$ & $0(4.471)$ \\
\hline
\end{tabular}

${ }^{\text {a }}$ Control, optimal conditions such as PBS, $\mathrm{pH} 7$, and $4{ }^{\circ} \mathrm{C}$.

${ }^{\mathrm{b}}$ Surviving phage titer, the mean of three experiments performed in triplicate on separated occasions, with the standard deviations $(\mathrm{SD} ; n=3$ ). 


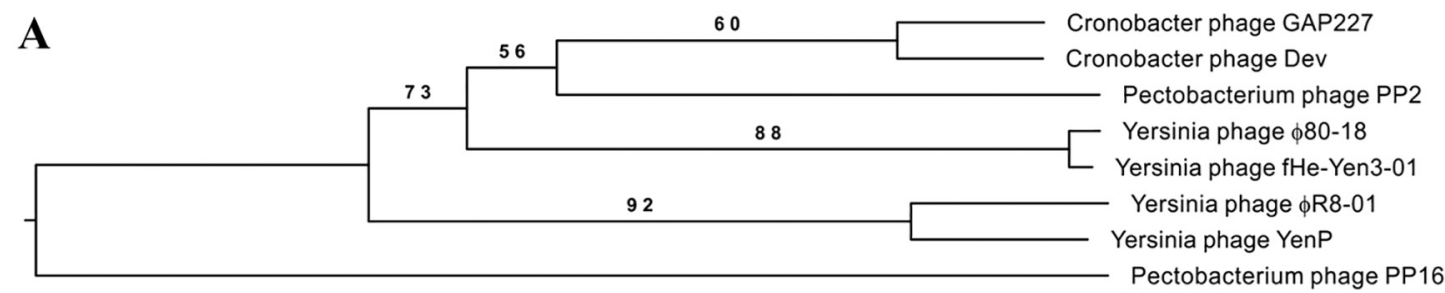

0.05

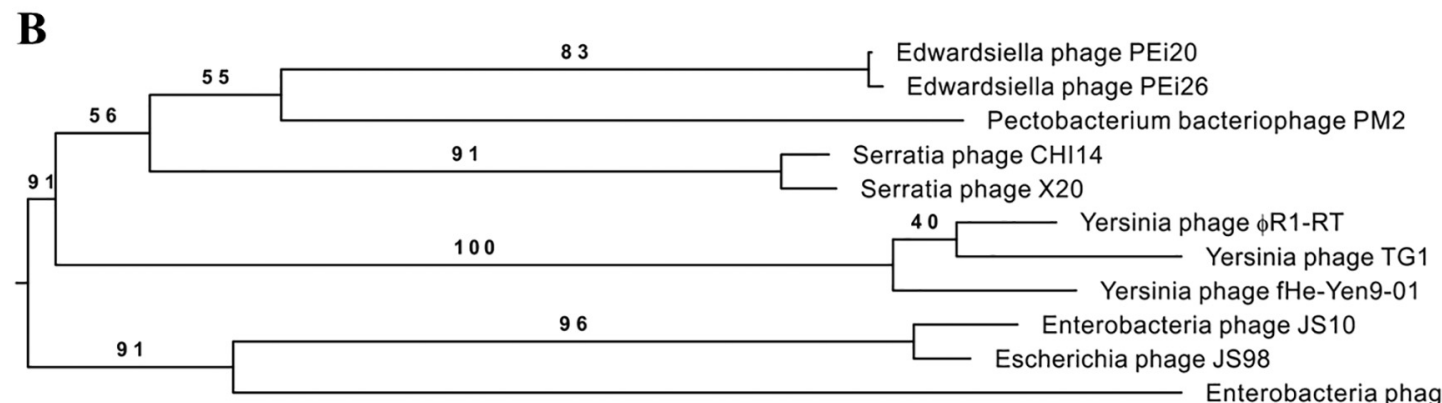

Enterobacteria phage T4

0.03

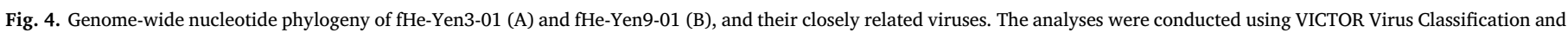

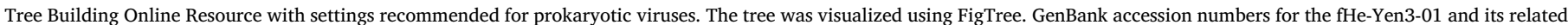

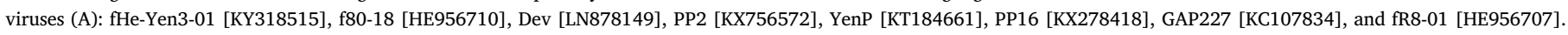

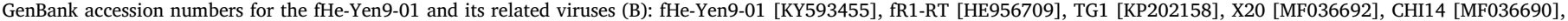
PEi26 [AP014715], PEi20 [AP014714], PM2 [KF835987], JS98 [EF469154], JS10 [EU863409], and T4 [AF158101].

between genes $g 170$ and g216. Comparative genomics showed that fHeYen9-01 shared approximately 84\% nucleotide sequence identity with vB_YenM_ $\phi R 1-R T$ and $76 \%$ with vB_YenM_TG1 (85\% identical to each other). Only for 36 of the fHe-Yen9-01 genes, the closest homolog in either vB_YenM_\$R1-RT or vB_YenM_TG1 could not be found (Fig. 5, Table S2). These phages, vB_YenM_ $\phi R 1-R T$, vB_YenM_TG1, and fHeYen9-01, are phylogenetically clustered in the same group (Fig. 4B).

Genes related to lysogeny were not found in the genome of either phage, and none of their genes were associated with undesirable properties, such as virulence factors that might preclude their use as biocontrol agents.

\subsection{Phage application to $Y$. enterocolitica-contaminated foods, kitchen utensils, and artificial hands}

To examine the bacteriolytic effect of fHe-Yen9-01 applied to food, samples of raw pork, RTE pork, and milk were treated with this phage after having been inoculated with $Y$. enterocolitica O:9 strain Ruokola/ 71 (Fig. 6). In the control samples (inoculated with bacteria but not treated with phages), the number of CFUs increased during the experiment: from $2.3 \times 10^{3} \mathrm{CFU} / \mathrm{g}$ to $7.84 \times 10^{6} \mathrm{CFU} / \mathrm{g}$ in raw pork, from $2.1 \times 10^{3} \mathrm{CFU} / \mathrm{g}$ to $5.72 \times 10^{6} \mathrm{CFU} / \mathrm{g}$ in RTE pork, and $4.15 \times 10^{3} \mathrm{CFU} / \mathrm{ml}$ to $2.41 \times 10^{7} \mathrm{CFU} / \mathrm{ml}$ in milk (Fig. 6). In contrast, bacterial growth in raw pork, RTE pork, and milk in the treatment group was inhibited throughout the experiment, with counts decreasing from $2.3 \times 10^{3} \mathrm{CFU} / \mathrm{g}$ to $2.12 \times 10^{2} \mathrm{CFU} / \mathrm{g}, 2.1 \times 10^{3} \mathrm{CFU} / \mathrm{g}$ to $3.8 \times 10 \mathrm{CFU} / \mathrm{g}, \quad 4.15 \times 10^{3} \mathrm{CFU} / \mathrm{ml}$ to below the detection limit $(<10 \mathrm{CFU} / \mathrm{ml}$ ), respectively (Fig. 6). The phage titer increased in raw pork and milk for the first 12 (raw pork; from $1.77 \times 10^{8}$ to $3.15 \times 10^{8} \mathrm{PFU} / \mathrm{g}$ ) and 24 (milk; from $1.98 \times 10^{8}$ to $3.0 \times 10^{8} \mathrm{PFU} /$ $\mathrm{ml}$ ), respectively, and the phage titer decreased thereafter in these food samples (Fig. 6). High phage titers were recorded in RTE pork until the end of the experiment: between $1.34 \times 10^{8}$ and $1.94 \times 10^{8} \mathrm{PFU} / \mathrm{g}$ (Fig. 6). In all food samples, high phage titers (at least $10^{7} \mathrm{PFU} / \mathrm{g}$ or ml) were maintained throughout the experiment (Fig. 6).

To determine the efficiency of fHe-Yen9-01 treatment of kitchen utensils and hands contaminated with $Y$. enterocolitica, this phage was applied to wooden and plastic cutting boards, knives, and artificial hands after inoculation with this bacterium and subsequent storage in dry or humid conditions (Fig. 7). In all cases, CFU counts remained constant for $2 \mathrm{~h}$ after the beginning of the experiment; thereafter, no bacteria were detectable (Fig. 7). In the control group (contaminated with bacteria but not phage-treated), CFU counts increased for $1 \mathrm{~h}$, and high CFU counts (higher than $10^{3} \mathrm{CFU} / \mathrm{cm}^{2}$ or $\mathrm{ml}$ ) were maintained until $2 \mathrm{~h}$ (Fig. 7). In wooden and plastic cutting boards, humid conditions resulted in higher CFU counts than dry conditions. The highest $\mathrm{CFU}$ values were recorded with wooden cutting boards after $1 \mathrm{~h}$ and plastic cutting boards after $2 \mathrm{~h}$ in humid conditions, $4.0 \times 10^{4} \mathrm{CFU} / \mathrm{cm}^{2}$ and $4.5 \times 10^{4} \mathrm{CFU} / \mathrm{cm}^{2}$ (Fig. 7). No significant difference of $\mathrm{CFU}$ values was observed between dry and humid conditions in knives and artificial hands (Fig. 7). In the treatment group, bacterial growth was inhibited throughout the experiment, with the following counts after $2 \mathrm{~h}$ (bacterial counts in the control and treatment groups are given, respectively): wooden cutting boards, $9.6 \times 10^{3}$ and $9.5 \times 10^{2} \mathrm{CFU} / \mathrm{cm}^{2}$ (dry condition), $2.69 \times 10^{4}$ and $5.55 \times 10^{2} \mathrm{CFU} / \mathrm{cm}^{2}$ (humid condition); plastic cutting boards, $2.09 \times 10^{4}$ and $2.9 \times 10^{2} \mathrm{CFU} / \mathrm{cm}^{2}$ (dry), $4.5 \times 10^{4}$ and $3.95 \times 10^{2} \mathrm{CFU} / \mathrm{cm}^{2}$ (humid); knives, $2.0 \times 10^{3}$ and $2.45 \times 10^{2} \mathrm{CFU} / \mathrm{ml}$ (dry), $2.76 \times 10^{3}$ and $5.0 \times 10^{2} \mathrm{CFU} / \mathrm{ml}$ (humid); artificial hands, $4.13 \times 10^{3}$ and $4.0 \times 10^{2} \mathrm{CFU} / \mathrm{ml}$ (dry), $3.55 \times 10^{3}$ and $4.5 \times 10^{2} \mathrm{CFU} / \mathrm{ml}$ (humid) (Fig. 7). However, phage titers under dry and humid conditions did not significantly differ, with titers after $2 \mathrm{~h}$ being as follows: wooden cutting boards, $3.68 \times 10^{8}$ and $2.45 \times 10^{8} \mathrm{PFU} / \mathrm{cm}^{2}$; plastic cutting boards, $1.95 \times 10^{8}$ and $4.04 \times 10^{8} \mathrm{PFU} / \mathrm{cm}^{2}$; knives, $2.45 \times 10^{8}$ and $4.1 \times 10^{8} \mathrm{PFU} / \mathrm{ml}$; 
$\mathbf{A}$
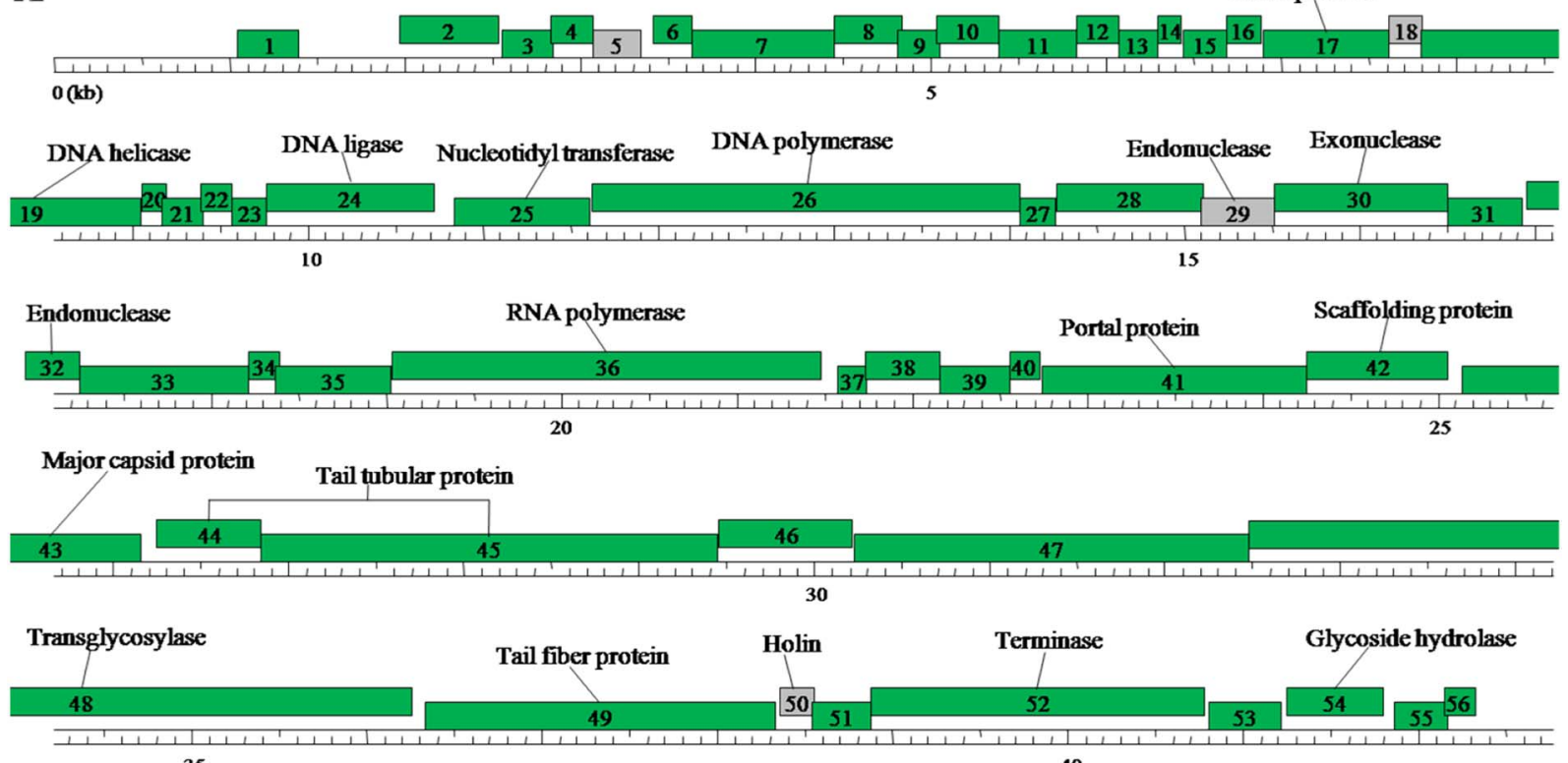

B

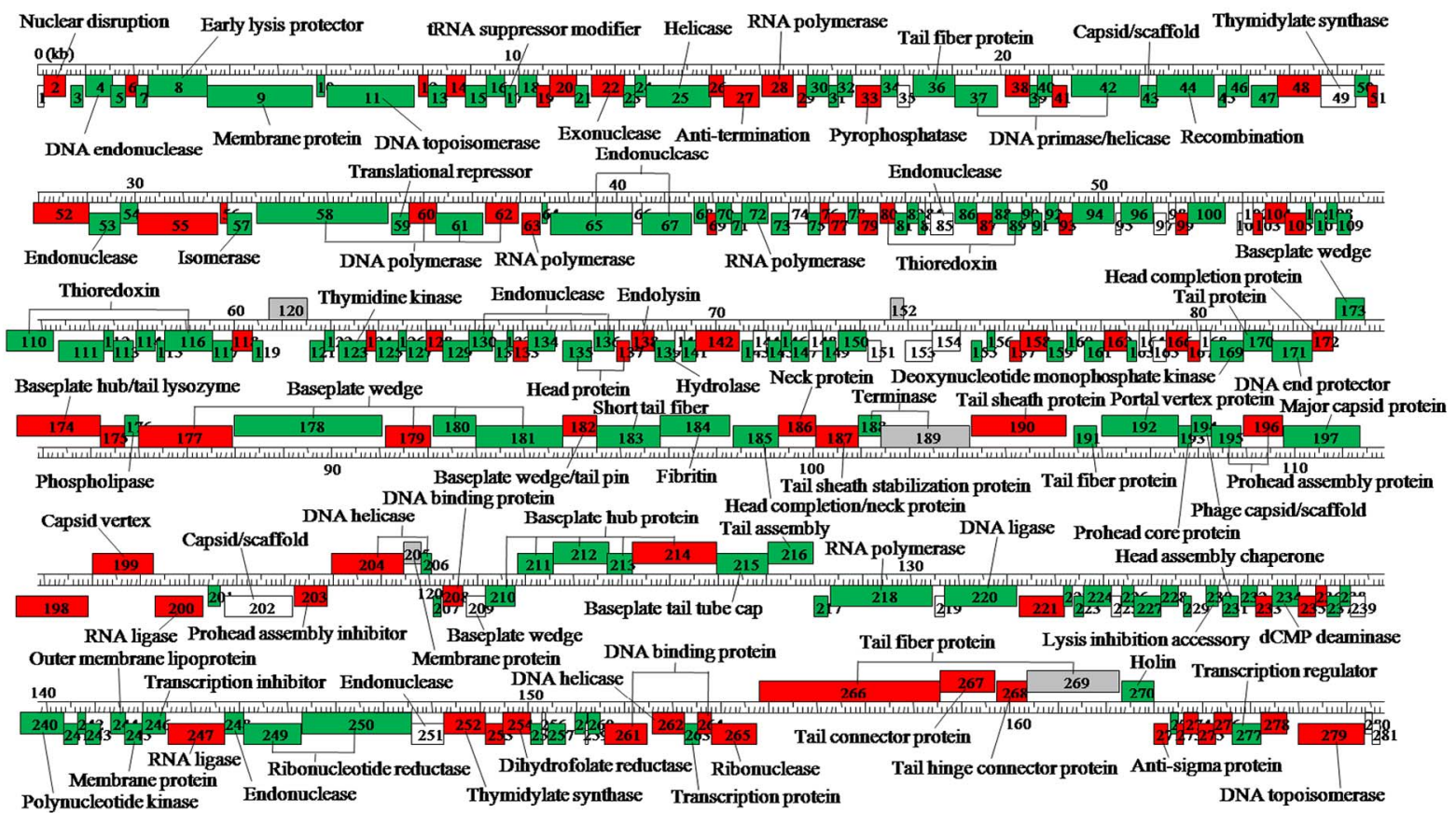

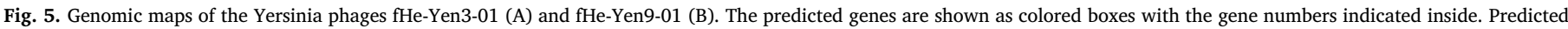

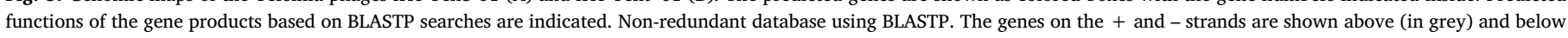

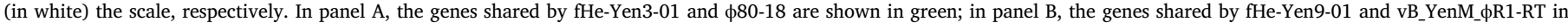
green, and by fHe-Yen9-01 and vB_YenM_TG1 in red. (For interpretation of the references to colour in this figure legend, the reader is referred to the web version of this article.)

artificial hands, $4.7 \times 10^{8}$ and $5.85 \times 10^{8} \mathrm{PFU} / \mathrm{ml}$, respectively (Fig. 7).

\subsection{Safety assessment of phage preparation}

Both the highly purified and the crude phage preparations were completely safe when administered to mice intragastrically and did not affect the physical condition or survival of the mice over the 28 days of observation. Also, the heat-inactivated lysate showed no adverse effects. This result is remarkable as the crude lysate very likely contained bacterial degradation products and thereby also putative toxins.

\section{Discussion}

In the current study, four virulent phages, named fHe-Yen3-01, fHeYen9-01, fHe-Yen9-02, and fHe-Yen9-03, were isolated from a sewage treatment facility in Viikki, Helsinki, Finland. fHe-Yen3-01 and fHeYen9-01 were selected for further study, including genomic characterization, due to their promising characteristics. Analysis of their genomes failed to identify sequences similar to known lysogenic genes, indicating that these are lytic phages. This result supports the potential utility of fHe-Yen3-01 and fHe-Yen9-01 in biocontrol, given that lytic phages are regarded as more suitable for phage therapy (Gutiérrez 

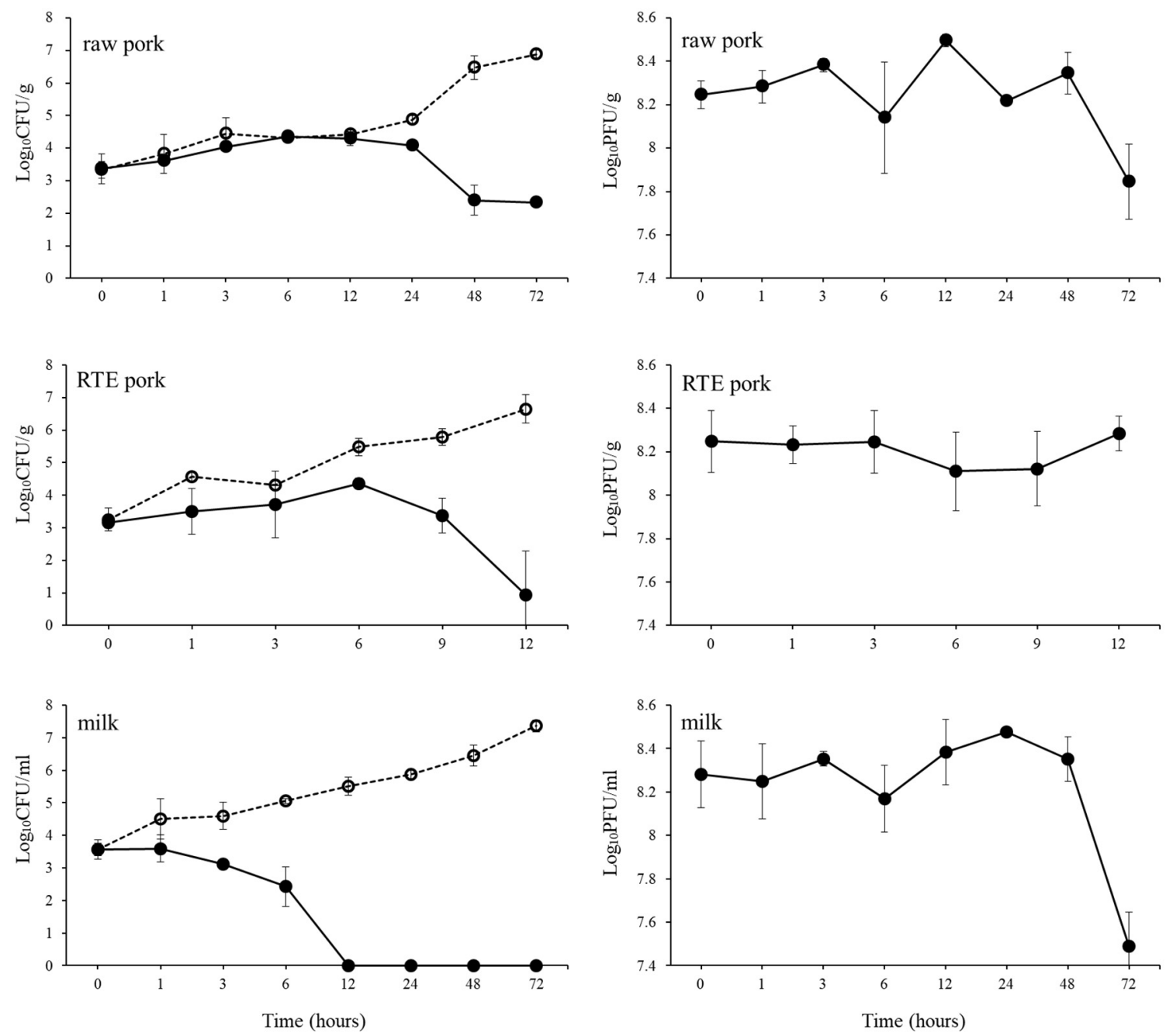

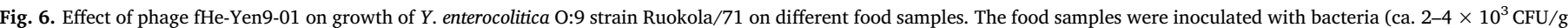

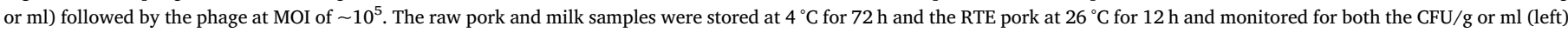

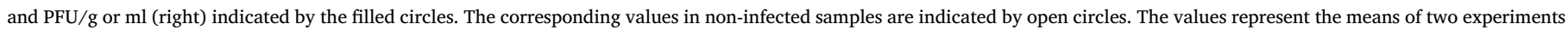
performed with triplicate samples on separate occasions, and error bars represent standard deviations $(n=2)$.

et al., 2010). Members of Myoviridae are generally considered to have broader host ranges than those of Siphoviridae and Podoviridae (Wichels et al., 1998). Consistent with this, the Myoviridae phage fHe-Yen9-01 demonstrated the broadest host range, being able to infect 61.3\% (65/ 106) of the Yersinia strains and $65.4 \%(53 / 81)$ of the $Y$. enterocolitica strains used in this study. A broad host range is an advantage for the application of phages in biocontrol, as a single agent can be used to control several bacteria (Jun et al., 2016). fHe-Yen9-01 also demonstrated greater bacteriolytic activity than fHe-Yen3-01 in the present work. These findings suggest that of the phages tested, fHe-Yen9-01 has the most promising characteristics for use as an agent to reduce the spreading of $Y$. enterocolitica from foodstuffs to humans. In addition, this phage proved to be stable when subjected to various stresses likely to be encountered during food processing. As a result, fHe-Yen9-01 was selected for further testing in a biocontrol assay.

We designed two experimental models to simulate what is considered to be the most important $Y$. enterocolitica infection route according to the prevention guidelines issued by the Centers for Disease Control and Prevention (CDC, 2016). One was a model of food contamination, recognized as a relatively common source of $Y$. enterocolitica infections, and the other a model of kitchen utensil contamination, which is likely to occur during food preparation at markets and restaurants and occasionally in domestic kitchens. These models of the food market environment, which includes a great variety of $Y$. enterocolitica transmission routes, were then used to evaluate the protective effect of fHe-Yen9-01 under conditions analogous to real-life situations. The in vitro test of host cell lysis indicated that bacterial growth was the more effectively inhibited by fHe-Yen9-01 at the higher MOI. Therefore, phage application in the experimental models was designed to yield a final MOI having a minimum of $10^{4}$.

A number of Yersinia-specific phages have been documented to date (Kiljunen et al., 2005a, 2005b; Leon-Velarde et al., 2016; Pajunen et al., 2000, 2001; Schwudke et al., 2008; Skurnik et al., 2012). Such phages have been isolated and characterized (Leon-Velarde et al., 2016; Salem et al., 2015) and phage application in meat at $4^{\circ} \mathrm{C}$ against $Y$. enterocolitica was studied (Orquera et al., 2012). However, application of phages on the surface of RTE food or kitchen utensils against $Y$. enterocolitica has not been studied. Certain foods pose a yersiniosis risk, such as the German minced raw pork dish "met", and the risk of $Y$. enterocolitica infection associated with the consumption of pork may be considerable even after cooking. Firstly, Y. enterocolitica can survive in cooked pork products, although sufficient cooking should eliminate the bacteria (Grahek-Ogden et al., 2007). Secondly, a risk of Y. enterocolitica infection remains even when pork is correctly cooked, owing to the possibility of surface contamination during processing of RTE products. In this study, the efficiency of phage application in 

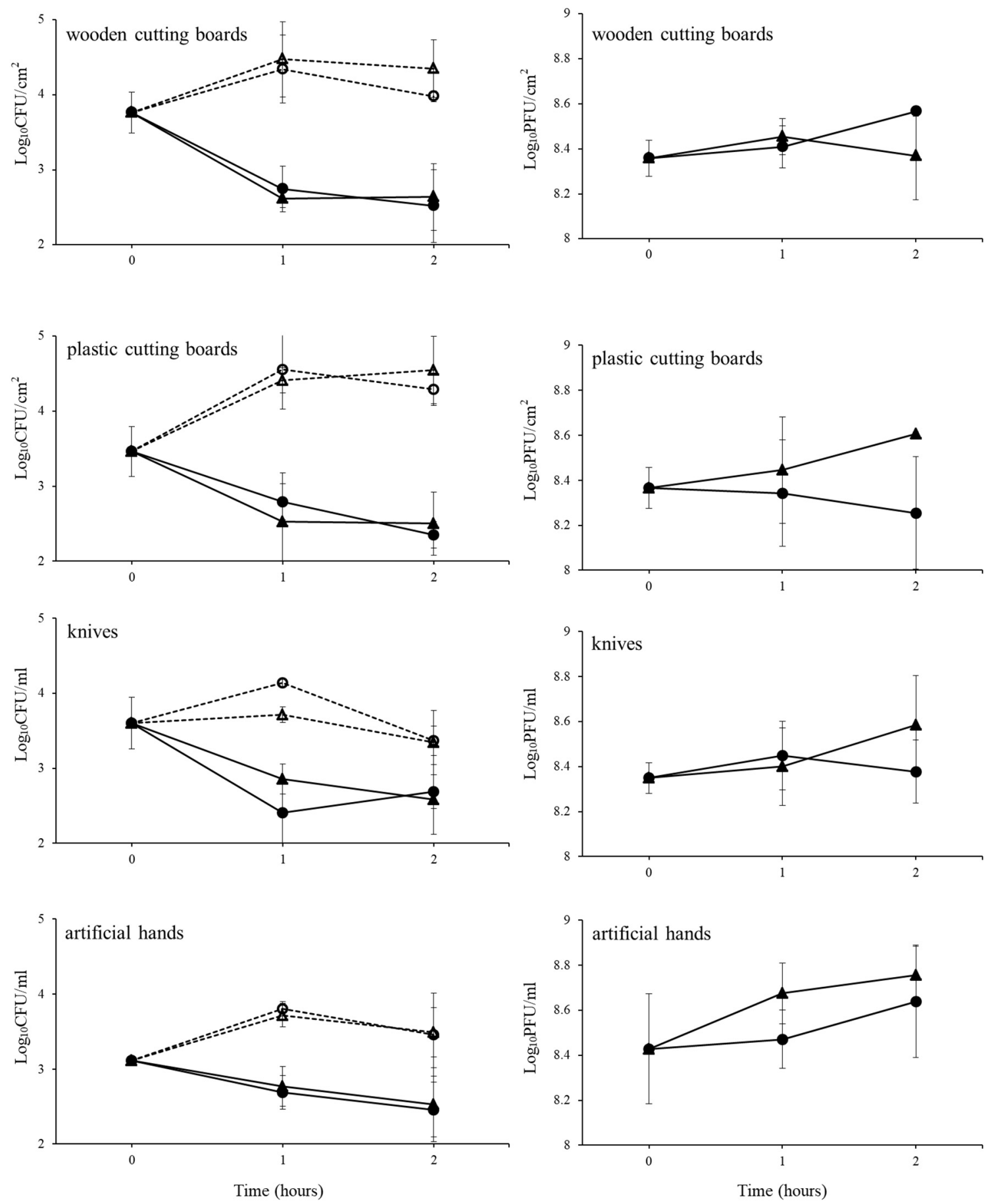

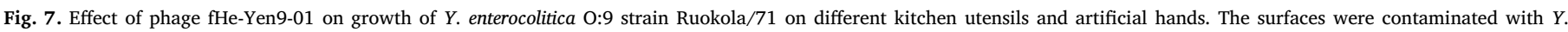

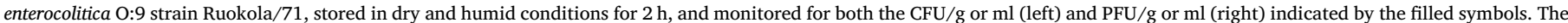

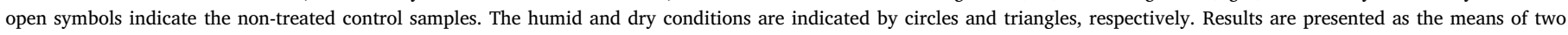
experiments performed in duplicate, and the error bars represent standard deviations $(n=2)$.

controlling $Y$. enterocolitica contamination of RTE pork was examined at $26^{\circ} \mathrm{C}$ up to $12 \mathrm{~h}$ after bacterial inoculation as this time was sufficient for the bacteria to grow on the non-treated samples, reaching close to $10^{7} \mathrm{CFU} / \mathrm{g}$. In the minced meat and milk samples the same levels of bacteria were reached in $72 \mathrm{~h}$ at $4{ }^{\circ} \mathrm{C}$. Milk is thought to be a source of human Yersinia infections, although this may not be a significant concern in the many countries where pasteurization is used. In accordance to the psychrotrophic nature of Yersinia (Hanna et al., 1977; Swaminathan et al., 1982), bacterial counts in raw pork and milk significantly increased during incubation at $4{ }^{\circ} \mathrm{C}$ in the present work, emphasizing the importance of good hygienic procedures for safe food storage.

Cutting boards, knives, and hands have been identified as important causes of cross-contamination with foodborne pathogens in kitchens (Zhao et al., 1998). We focused on these objects as they are crucial factors in the successful application of phages in various situations. In this study, both wooden and plastic cutting boards were examined to establish if these materials confer different levels of $Y$. enterocolitica contamination risk. No significant difference was observed between the two, although bacterial counts were slightly lower on the wooden 
cutting boards. This appears to be due to the different surfaces of these materials, in that the plastic cutting board was uneven and bumpy, which may have delayed its drying, whereas the wooden cutting board was even and smooth. In general, an uneven surface is regarded as a disadvantage for phage application, as it physically hinders the distribution of phage particles, preventing them from reaching target bacteria (Guenther et al., 2009). The development of effective phage application methods, such as sprays, should be taken into consideration to maximize treatment efficacy. Because bacterial counts on cutting boards stored under humid conditions were higher than on those kept dry, it would be desirable to dry cutting boards as soon as possible, although this is hard to achieve in the kitchen environment. In addition, the presence of food residues may increase the risk of $Y$. enterocolitica spreading associated with kitchen utensils, especially when working with gloves, as they are commonly reused.

In summary, given their favorable attributes, the Yersinia phages fHe-Yen3-01 and fHe-Yen9-01 were selected for further study and genomic analysis, which indicated the absence of undesirable genes that may have prevented their application in biocontrol. Neither the highly purified nor the crude fHe-Yen9-01 lysate resulted in any physiological signs of toxicity after oral administration to mice. As no mice showed any adverse effects, we can conclude that the phage preparations were safe at least when administered i.g.. As phages are naturally found in all food products (Soni et al., 2010), even the strictest regulations concerning their application to food and kitchen utensils cannot prohibit their use. This study emphasizes the potential benefits of applying phages to various objects, from food to kitchen utensils, for the control of foodborne infections.

Supplementary data to this article can be found online at https:// doi.org/10.1016/j.ijfoodmicro.2018.02.007.

\section{Acknowledgements}

This work was supported by the Basic Science Research Program through the National Research Foundation of Korea (NRF) funded by the Ministry of Education (2017R1C1B2004616). MS received funding from the Helsinki University Central Hospital special state subsidy for health science research grants (projects TYH2013237, TYH2015411 and TYH2016249), the Academy of Finland (project 1288701), and the Jane \& Aatos Erkko Foundation (Decision 24.10.2016).

\section{References}

Adams, M., 1959. Bacteriophages. Interscience Publishers, New York.

Bengoechea, J.A., Najdenski, H., Skurnik, M., 2004. Lipopolysaccharide O antigen status of Yersinia enterocolitica O:8 is essential for virulence and absence of $\mathrm{O}$ antigen affects the expression of other Yersinia virulence factors. Mol. Microbiol. 52, 451-469.

Bergh, Ø., Børsheim, K.Y., Bratbak, G., Heldal, M., 1989. High abundance of viruses found in aquatic environments. Nature $340,467-468$.

Besemer, J., Lomsadze, A., Borodovsky, M., 2001. GeneMarkS: a self-training method for prediction of gene starts in microbial genomes. Implications for finding sequence motifs in regulatory regions. Nucleic Acids Res. 29, 2607-2618.

Bottone, E.J., 1999. Yersinia enterocolitica: overview and epidemiologic correlates. Microbes Infect. 1, 323-333.

Bozcal, E., Uzel, A., Aydemir, S., Skurnik, M., 2015. Isolation of pathogenic Yersinia enterocolitica strains from different sources in Izmir region, Turkey. Folia Microbiol. 60, 523-529.

CDC, Centers for Disease Control and Prevention, 2016. Yersinia enterocolitica (Yersiniosis). Available at. https://www.cdc.gov/yersinia/ (updated October 24, 2016).

Coil, D., Jospin, G., Darling, A.E., 2015. A5-miseq: an updated pipeline to assemble microbial genomes from Illumina MiSeq data. Bioinformatics 31, 587-589.

Delcher, A.L., Harmon, D., Kasif, S., White, O., Salzberg, S.L., 1999. Improved microbial gene identification with GLIMMER. Nucleic Acids Res. 27, 4636-4641.

EFSA, ECDC, 2015. The European Union summary report on trends and sources of zoonoses, zoonotic agents and food-borne outbreaks in 2013. EFSA J. 13, 3991.

Ellis, E.L., Delbruck, M., 1939. The growth of bacteriophage. J. Gen. Physiol. 22, 365-384.

Farris, J.S., 1972. Estimating phylogenetic trees from distance matrices. Am. Nat. 106, 645-667.

Gemski, P., Lazere, J.R., Casey, T., 1980. Plasmid associated with pathogenicity and calcium dependency of Yersinia enterocolitica. Infect. Immun. 27, 682-685.
Göker, M., García-Blázquez, G., Voglmayr, H., Tellería, M.T., Martín, M.P., 2009. Molecular taxonomy of phytopathogenic fungi: a case study in Peronospora. PLoS One 4, e6319.

Grahek-Ogden, D., Schimmer, B., Cudjoe, K.S., Nygård, K., Kapperud, G., 2007. Outbreak of Yersinia enterocolitica serogroup 0:9 infection and processed pork, Norway. Emerg. Infect. Dis. 13, 754-756.

Guenther, S., Huwyler, D., Richard, S., Loessner, M.J., 2009. Virulent bacteriophage for efficient biocontrol of Listeria monocytogenes in ready-to-eat foods. Appl. Environ. Microbiol. 75, 93-100.

Gutiérrez, D., Martínez, B., Rodríguez, A., García, P., 2010. Isolation and characterization of bacteriophages infecting Staphylococcus epidermidis. Curr. Microbiol. 61, 601-608.

Hanna, M.O., Stewart, J.C., Zink, D.L., Carpenter, Z.L., Vanderzant, C., 1977. Development of Yersinia enterocolitica on raw and cooked beef and pork at different temperatures. J. Food Sci. 42, 1180-1184.

Jun, J.W., Kim, H.J., Yun, S.K., Chai, J.Y., Park, S.C., 2014a. Eating oysters without risk of vibriosis: application of a bacteriophage against Vibrio parahaemolyticus in oysters. Int. J. Food Microbiol. 188, 31-35.

Jun, J.W., Shin, T.H., Kim, J.H., Shin, S.P., Han, J.E., Heo, G.J., De Zoysa, M., Shin, G.W., Chai, J.Y., Park, S.C., 2014b. Bacteriophage therapy of a Vibrio parahaemolyticus infection caused by a multiple-antibiotic-resistant O3:K6 pandemic clinical strain. J. Infect. Dis. 210, 72-78.

Jun, J.W., Kim, H.J., Yun, S.K., Chai, J.Y., Lee, B.C., Park, S.C., 2016. Isolation and comparative genomic analysis of T1-like Shigella bacteriophage pSf-2. Curr. Microbiol. 72, 235-241.

Kapperud, G., Skarpeid, H., Solberg, R., Bergan, T., 1985. Outer membrane proteins and plasmids in different Yersinia enterocolitica serogroups isolated from man and animals. Acta Pathol. Microbiol. Immunol. Scand. B 93, 27-35.

Kay, B.A., Wachsmuth, K., Gemski, P., Feeley, J.C., Quan, T.J., Brenner, D.J., 1983. Virulence and phenotypic characterization of Yersinia enterocolitica isolated from humans in the United States. J. Clin. Microbiol. 17, 128-138.

Kiljunen, S., Hakala, K., Pinta, E., Huttunen, S., Pluta, P., Gador, A., Lönnberg, H., Skurnik, M., 2005a. Yersiniophage $\phi R 1-37$ is a tailed bacteriophage having a $270 \mathrm{~kb}$ DNA genome with thymidine replaced by deoxyuridine. Microbiology 151, 4093-4102.

Kiljunen, S., Vilen, H., Pajunen, M., Savilahti, H., Skurnik, M., 2005b. Nonessential genes of phage $\phi Y e O 3-12$ include genes involved in adaptation to growth on Yersinia enterocolitica serotype O:3. J. Bacteriol. 187, 1405-1414.

Krogh, A., Larsson, B., von Heijne, G., Sonnhammer, E.L.L., 2001. Predicting transmembrane protein topology with a hidden Markov model: application to complete genomes. J. Mol. Biol. 305, 567-580.

Laukkanen, R., Hakkinen, M., Lundén, J., Fredriksson-Ahomaa, M., Johansson, T., Korkeala, H., 2010. Evaluation of isolation methods for pathogenic Yersinia enterocolitica from pig intestinal content. J. Appl. Microbiol. 2010, 956-964.

Lefort, V., Desper, R., Gascuel, O., 2015. FastME 2.0: a comprehensive, accurate, and fast distance-based phylogeny inference program. Mol. Biol. Evol. 32, 2798-2800.

Leon-Velarde, C.G., Happonen, L., Pajunen, M., Leskinen, K., Kropinski, A.M., Mattinen, L., Rajtor, M., Zur, J., Smith, D., Chen, S., Nawaz, A., Johnson, R.P., Odumeru, J.A., Griffiths, M.W., Skurnik, M., 2016. Yersinia enterocolitica-specific infection by bacteriophages TG1 and $\phi \mathrm{R} 1-\mathrm{RT}$ is dependent on temperature-regulated expression of the phage host receptor ompF. Appl. Environ. Microbiol. 82, 5340-5353.

Mai, V., Ukhanova, M., Reinhard, M.K., Li, M., Sulakvelidze, A., 2015. Bacteriophage administration significantly reduces Shigella colonization and shedding by Shigella challenged mice without deleterious side effects and distortions in the gut microbiota. Bacteriophage 5 (4).

Maura, D., Debarbieux, L., 2011. Bacteriophages as twenty-first century antibacterial tools for food and medicine. Appl. Microbiol. Biotechnol. 90, 851-859.

McNally, A., Thomson, N.R., Reuter, S., Wren, B.W., 2016. 'Add, stir and reduce': Yersinia spp. as model bacteria for pathogen evolution. Nat. Rev. Microbiol. 14, 177-190.

Meier-Kolthoff, J.P., Göker, M., 2017. VICTOR: genome-based phylogeny and classification of prokaryotic viruses. Bioinformatics 33, 3396-3404.

Meier-Kolthoff, J.P., Auch, A.F., Klenk, H.P., Göker, M., 2013. Genome sequence-based species delimitation with confidence intervals and improved distance functions. BMC Bioinf. 14, 60.

Meier-Kolthoff, J.P., Hahnke, R.L., Petersen, J., Scheuner, C., Michael, V., Fiebig, A., Rohde, C., Rohde, M., Fartmann, B., Goodwin, L.A., Chertkov, O., Reddy, T.B.K., Pati, A., Ivanova, N.N., Markowitz, V., Kyrpides, N.C., Woyke, T., Göker, M., Klenk, H.P., 2014. Complete genome sequence of DSM $30083^{\mathrm{T}}$, the type strain $\left(\mathrm{U} 5 / 41^{\mathrm{T}}\right.$ ) of Escherichia coli, and a proposal for delineating subspecies in microbial taxonomy. Stand. Genomic Sci. 9, 2 .

Murros-Kontiainen, A., Fredriksson-Ahomaa, M., Korkeala, H., Johansson, P., Rahkila, R., Björkroth, J., 2011a. Yersinia nurmii sp. nov. Int. J. Syst. Evol. Microbiol. 61, $2368-2372$.

Murros-Kontiainen, A., Johansson, P., Niskanen, T., Fredriksson-Ahomaa, M., Korkeala, H., Björkroth, J., 2011b. Yersinia pekkanenii sp. nov. Int. J. Syst. Evol. Microbiol. 61, 2363-2367.

Orquera, S., Gölz, G., Hertwig, S., Hammerl, J., Sparborth, D., Joldic, A., Alter, T., 2012 Control of Campylobacter spp. and Yersinia enterocolitica by virulent bacteriophages. J. Mol. Genet. Med. 6, 273-278.

Pajunen, M., Kiljunen, S., Skurnik, M., 2000. Bacteriophage $\phi Y e O 3-12$, specific for Yersinia enterocolitica serotype 0:3, is related to coliphages T3 and T7. J. Bacteriol. 182, 5114-5120.

Pajunen, M.I., Kiljunen, S.J., Söderholm, M.E.L., Skurnik, M., 2001. Complete genomic sequence of the lytic bacteriophage $\phi Y e O 3-12$ of Yersinia enterocolitica serotype 0:3 J. Bacteriol. 183, 1928-1937.

Perry, R.D., Brubaker, R.R., 1983. Vwa ${ }^{+}$phenotype of Yersinia enterocolitica. Infect. Immun. 40, 166-171. 
Petersen, T.N., Brunak, S., von Heijne, G., Nielsen, H., 2011. SignalP 4.0: discriminating signal peptides from transmembrane regions. Nat. Methods 8, 785-786.

Portnoy, D.A., Moseley, S.L., Falkow, S., 1981. Characterization of plasmids and plasmidassociated determinants of Yersinia enterocolitica pathogenesis. Infect. Immun. 31, 775-782.

Prpic, J.K., Robins-Browne, R.M., Davey, R.B., 1983. Differentation between virulent and avirulent Yersinia enterocolitica isolates by using congo red agar. J. Clin. Microbiol. 18, 486-490.

Reuter, S., Connor, T.R., Barquist, L., Walker, D., Feltwell, T., Harris, S.R., Fookes, M. Hall, M.E., Petty, N.K., Fuchs, T.M., Corander, J., Dufour, M., Ringwood, T., Savin, C., Bouchier, C., Martin, L., Miettinen, M., Shubin, M., Riehm, J.M., Laukkanen-Ninios, R., Sihvonen, L.M., Siitonen, A., Skurnik, M., Falcão, J.P., Fukushima, H., Scholz, H.C., Prentice, M.B., Wren, B.W., Parkhill, J., Carniel, E., Achtman, M., McNally, A., Thomson, N.R., 2014. Parallel independent evolution of pathogenicity within the genus Yersinia. Proc. Natl. Acad. Sci. U. S. A. 111, 6768-6773.

Salem, M., Virtanen, S., Korkeala, H., Skurnik, M., 2015. Isolation and characterization of Yersinia-specific bacteriophages from pig stools in Finland. J. Appl. Microbiol. 118, 599-608.

Sambrook, J., Fritsch, E.F., Maniatis, T., 1989. Molecular Cloning: A Laboratory Manual, 2nd ed. Cold Spring Harbor Laboratory Press, Cold Spring Harbor, NY.

Schiemann, D.A., 1984. Antigenic identity of Yersinia enterocolitica serotypes O:Tacoma and O21. J. Clin. Microbiol. 20, 831-832.

Schiemann, D.A., Devenish, J.A., 1982. Relationship of HeLa cell infectivity to biochemical, serological, and virulence characteristics of Yersinia enterocolitica. Infect. Immun. 35, 497-506.

Schwudke, D., Ergin, A., Michael, K., Volkmar, S., Appel, B., Knabner, D., Konietzny, A., Strauch, E., 2008. Broad-host-range Yersinia phage PY100: genome sequence, proteome analysis of virions, and DNA packaging strategy. J. Bacteriol. 190, 332-342.

Skurnik, M., 1984. Lack of correlation between the presence of plasmids and fimbriae in Yersinia enterocolitica and Yersinia pseudotuberculosis. J. Appl. Bacteriol. 56, 355-363.

Skurnik, M., 1985. Studies on the virulence plasmids of Yersinia species. Acta Univ. Ouluensis Ser. A Sci. Rerum Nat. 169, 1-61.

Skurnik, M., Toivanen, P., 1991. Intervening sequences (IVSs) in the 23S ribosomal RNA genes of pathogenic Yersinia enterocolitica strains. The IVSs in Y. enterocolitica and
Salmonella typhimurium have a common origin. Mol. Microbiol. 5, 585-593.

Skurnik, M., Toivonen, S., 2011. Identification of distinct lipopolysaccharide patterns among Yersinia enterocolitica and Y. enterocolitica-like bacteria. Biochemistry (Mosc) 76, 823-831.

Skurnik, M., Nurmi, T., Granfors, K., Koskela, M., Tiilikainen, A.S., 1983. Plasmid associated antibody production against Yersinia enterocolitica in man. Scand. J. Infect. Dis. 15, 173-177.

Skurnik, M., Hyytiäinen, H., Happonen, L.J., Kiljunen, S., Datta, N., Mattinen, L., Williamson, K., Kristo, P., Szeliga, M., Kalin-Mänttäri, L., Ahola-Iivarinen, E., Kalkkinen, N., Butcher, S.J., 2012. Characterization of the genome, proteome, and structure of yersiniophage $\phi R 1-37$. J. Virol. 86, 12625-12642.

Soni, K.A., Nannapaneni, R., Hagens, S., 2010. Reduction of Listeria monocytogenes on the surface of fresh channel catfish fillets by bacteriophage Listex P100. Foodborne Pathog. Dis. 7, 427-434.

Swaminathan, B., Harmon, M.C., Mehlman, I.J., 1982. Yersinia enterocolitica. J. Appl. Bacteriol. 52, 151-183.

Toma, S., Wauters, G., McClure, H.M., Morris, G.K., Weissfeld, A.S., 1984. O:13a,13b, a new pathogenic serotype of Yersinia enterocolitica. J. Clin. Microbiol. 20, 843-845.

Wauters, G., Janssens, M., Steigerwalt, A.G., Brenner, D.J., 1988. Yersinia mollaretii sp. nov. and Yersinia bercovieri sp. nov., formerly called Yersinia enterocolitica biogroups 3A and 3B. Int. J. Syst. Bacteriol. 38, 424-429.

Wichels, A., Biel, S.S., Gelderblom, H.R., Brinkhoff, T., Muyzer, G., Schútt, C., 1998. Bacteriophage diversity in the North Sea. Appl. Environ. Microbiol. 64, 4128-4133.

Zhang, L., Skurnik, M., 1994. Isolation of an $\mathrm{R}^{-} \mathrm{M}^{+}$mutant of Yersinia enterocolitica serotype $0: 8$ and its application in construction of rough mutants utilizing mini-Tn5 derivatives and lipopolysaccharide-specific phage. J. Bacteriol. 176, 1756-1760.

Zhang, L., Radzlejewska-Lebrecht, J., Krajewska-Pletraslk, D., Tolvanen, P., Skurnik, M., 1997. Molecular and chemical characterization of the lipopolysaccharide O-antigen and its role in the virulence of Yersinia enterocolitica serotype 0:8. Mol. Microbiol. 23, 63-76.

Zhao, P., Zhao, T., Doyle, M.P., Rubino, J.R., Meng, J., 1998. Development of a model for evaluation of microbial cross-contamination in the kitchen. J. Food Prot. 61, 960-963. 